\title{
Statistical Analysis of HIVIAIDS Awareness of Mothers: Ante-Natal Clinic of Braithwaite Memorial Specialist Hospital (BMH)
}

\author{
Orumie, Uamaka Cynthia ; Da-Wariboko, Asikiye Yvonne
}

Department of Mathematics amd Statistics, Uniport, 08064099683

\begin{abstract}
This study was conducted to analyse the HIV/AIDS awareness levels of mothers in Rivers state using mothers attending the Ante-natal clinic of the Braithwaite Memorial (BMH specialist) Hospital, Port Harcourt in Rivers State and the influence of their social demographic variables. This Descriptive cross sectional study was carried out among 344 Pregnant Mothers attending BMH Ante-natal clinic from June 2, 2015 to July 29, 2015. Simple random sampling method was applied to collect data which were analysed with simple percentage calculations and the chisquare test using SPSS.Higher percentage of the respondents were within the active reproductive age-group of 26-35 $(57 \%)$, most of them are married and living with their husband $(84.3 \%)$, also $58.7 \%$ of them have attained tertiary educational level and are predominantly Christians (94.3\%), 35\% of them are self- employed and mostly reside in urban area (96\%), finally $52 \%$ of them have at least a child. The chi-square $\mathrm{X}^{2}$ test result indicated that majority of the respondent have a high level of awareness on HIV/AIDS (96\%). The result further showed that there were significant association between the Marital status, Educational level, Parity and the Respondents' Level of awareness of HIV/AIDS, whereas, there were no significant association between Age, Religion inclination, Occupation , Residence and the Respondents' HIV/AIDS level of awareness.
\end{abstract}

\subsection{INTRODUCTION}

The First case of HIV/AIDS was reported in 1981 in the U.S.A, but its causative agent Human Immunodeficiency Virus (HIV) was first described in 1983 by Prof. Montagnier of the Pasteur Institute in Paris. The disease has ever since evolved into a global Epidemic with devastating Public health and Economic consequences, as described by Quinn (1996) and Gottlieb (2001).

World Health Organization (WHO) in 2012 estimated that HIV/AIDS has claimed the lives of more than 25million people and infected another 40million worldwide with $70 \%$ in the Sub-Saharan Africa and of which 3.4millions are Nigerians. Thus leaving 15 million orphans, a group uniquely susceptible to infection because of their social plight. United Nations and Acquired Immune Deficiency Syndrome (UNAIDS) in 2005 indicated that the global epidemic continues to outpace efforts to contain it, signifying a worldwide catastrophe.

Nigeria recorded its first case in Calabar, Cross Rivers State in 1986 and has also shown highest prevalence in urban areas, the North central zones, Benue state and among the 30-34 years age group. According to
National Agency for the Control of AIDS (NACA) fact sheet as at 2011, Its prevalence has declined among the Youth age group 15-24 from 6percent in 2001 to 4.3 percent in $2005,4.2$ percent in 2008 and 4.1percent in 2010.

Also In 2011, NACA announced that more than 80percent of HIV transmission in Nigeria is through heterosexual sex. The drivers of the epidemic in Nigeria include high illiteracy; high rate of sexually transmitted infections in vulnerable groups, poverty, Low condom use and General lack of perceived personal risk.

Prevention of Mother to Child Transmission (PMTCT) in 2015 revealed that Vertical or Mother to child transmission of HIV accounts for 10percent of its mode of transmission and accounts for 90percent of Paediatric HIV/AIDS cases, and that without an intervention, approximately 20-45percent infants born to HIV positive Mothers acquire the infection during pregnancy, delivery or breastfeeding.

NACA fact sheet (2011) showed that PMTCT Programs and Interventions commenced in Nigeria in 2001 with the establishment of over 640 sites in

This article is published under the terms of the Creative Commons Attribution License 4.0

Author(s) retain the copyright of this article. Publication rights with Alkhaer Publications.

Published at: http://www.ijsciences.com/pub/issue/2015-12/

DOI: 10.18483/ijSci.876; Online ISSN: 2305-3925; Print ISSN: 2410-4477 
Nigeria, in order to reduce the incidence of HIV transmission from mother to child by 2015 which is in line with the Millennium Development Goal (MDG) Braithwaite Memorial Hospital (BMH) is a Government owned hospital situated in the heart of Port Harcourt of Rivers state and delivers tertiary Health care services to its neighbouring communities.

According to Ibinabo (2009), BMH fulfils the Government of Nigeria generally accepted standards with respect to Prevention of Mother to child transmission by offering Pre-and Post-HIV test counselling for pregnant women, counselling HIVpositive women on infant feeding practices, and providing prophylactic Highly Active Anti-retroviral Therapy (HAART) to HIV positive women during pregnancy and delivery, by giving Zidovudine/Nevirapine syrups to the Neonates and Family Planning.

Nigeria in its global partnership with other International communities along side with NonGovernmental Organizations have stepped up strategies geared towards the prevention and control of the scourge in our communities over the years which include the PMTCT. Multiple factors have been identified which contribute to the amplification of HIV infections in Nigeria these include high illiteracy, high rate of sexually transmitted infections among vulnerable groups, inconsistent use of condoms etc.

In view of the above, this study seeks to analyse the HIV/AIDS Awareness of mothers and how their social demographic variables influence their awareness with particular reference to Braithwaite Memorial Specialist Hospital (BMH), Port Harcourt, Rivers State.

Section two and three gives brief history of the hospital and method of data collection respectively. Methodology, analyses and summaries are presented in section four, five, and six respectively, whereas section seven is the conclusion.

\section{BRIEF HISTORY OF THE HOSPITAL}

This study is confined to Braithwaite Memorial (Specialist) Hospital, Port Harcourt in Rivers State of Nigeria. Braithwaite Memorial (Specialist) Hospital is a Rivers State government owned hospital under the management of the Rivers State Hospitals Management Board and located at \#5 Harley Street, Forces Avenue, Old GRA, Port Harcourt in Rivers State.

It is a tertiary health institution with over 250 beds and renders health care services in Paediatrics, Internal Medicine, Surgery and Obstetrics/Gynaecology to the catchment areas. In the Obstetrics unit, it further renders prenatal services, Antenatal services, Postnatal services, PMTCT, Family Planning etc.

\section{POPULATION OF THE STUDY AND METHOD OF DATA COLLECTION}

The population of the study comprises of the Cross Section of pregnant mothers attending the Ante-natal clinic of BMH between the periods of June 2, 2015 to July 29, 2015. The mothers are aged 15 to 46years and have attained various levels of Educational qualification with different religious inclination and reside within Port Harcourt and its environs.

The Ante-natal register showed that a total of 3,368 registered in the Ante-natal clinic. Since the researcher could not interview the entire attendees of the various Ante-natal clinics in the hospital, the researcher used the simple random sampling technique to select the population for this study. The researcher with the assistance of few midwives administered the questionnaires only to mothers of second contact to the Ante-natal clinic, who were available at the period under review. Personal interview sessions were also held to explain and simplify the sections in the questionnaires which were not clear to them. First timer Ante-natal mothers were excluded from this study.

The researcher was able to reach 350 respondents since it was not possible to interview the entire population. Out of the 350 questionnaires that were administered, 347 were returned, and 3 out of the returned 347 were condemned by the researcher because they were not properly filled, hence a total of 344 questionnaires only were used as sample size for the study.

However, the data were from primary sources. Questionnaire was the main research instrument and it was divided into two sections. Section A was designed to provide information on personal data of the respondents, while section $\mathrm{B}$ consist of itemized questions aimed at eliciting appropriate responses from the respondents and arranged on a Likert Scale, with respect to level of awareness.

Question one to seven cover social demographic variables; while question eight to seventeen cover level of awareness. The likert scale categorized the level of awareness into three such as Low, Moderate and High.

\section{METHODOLOGY}

This chapter presents the procedures adopted in the study and they include the research method, population of the study, methods of data collection, analysis and interpretation.

\subsection{RESEARCH METHODOLOGY}


The study adopted a descriptive statistics such as, pie chart, bar chart and data collected were analysed using simple percentage and the research hypothesis were tested using CHI-SQUARE $\left(\mathrm{X}^{2}\right)$ analysis on SPSS.

\subsection{TEST STATISTIC}

The test statistic is:

$\chi^{2}=\sum_{i=1}^{k} \frac{\left(O_{i}-E_{i}\right)^{2}}{E_{i}} \approx \chi_{(\alpha,(r-1),(c-1))}^{2}$

\section{DATA ANALYSES}

The socio demographic characters used here are Age, Marital status, level of education, Religion, occupation, Residence and Parity.

\subsection{ANALYSIS ONE: LEVEL OF} AWARENESS

The table 6.1 below shows the level of awareness of HIV/AIDS among pregnant mothers attending BMH Ante-natal clinic using LIKERT SCALE and their respective percentage

Table 5.1: LEVEL OF AWARENESS

\begin{tabular}{|l|l|l|}
\hline LEVEL OF AWARENESS & FREQUENCY & PERCENTAGE \\
\hline LOW & 2 & $0.58 \%$ \\
\hline MODERATE & 12 & $3.48 \%$ \\
\hline HIGH & 330 & $95.93 \%$ \\
\hline TOTAL & 344 & $100 \%$ \\
\hline
\end{tabular}

From the harvested data as shown in table 5.1 above, $95.93 \%$ of the respondents have a high level of awareness, $3.48 \%$ of the respondents are moderately aware, whereas $0.58 \%$ of the respondents have low level of awareness of HIV/ AIDS.

Representing the above on a pie chart gives:

\section{frequency}

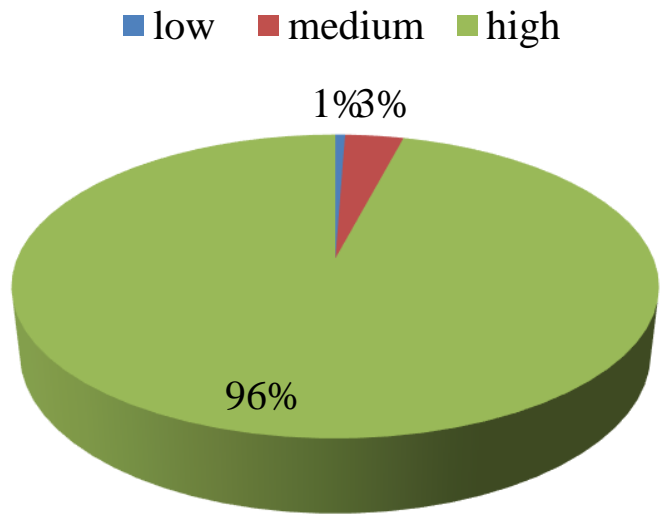

The above frequency is also represented in a bar graph below: 


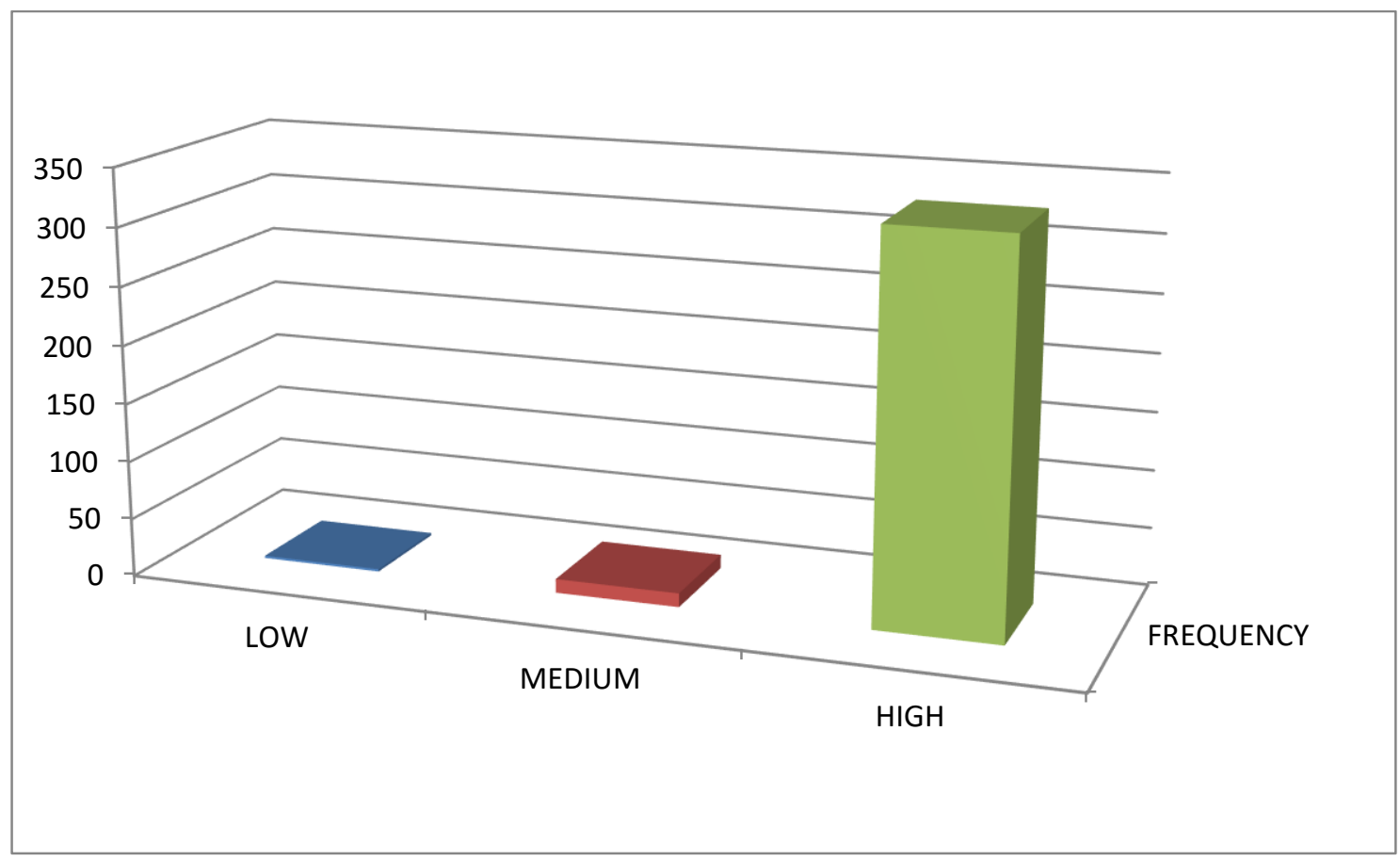

Fig 1: Bar graph of the level of awareness

5.2 DISTRIBUTION OF THE SOCIAL DEMOGRAPHIC VARIABLES AND PERCENTAGE OF RESPONDENTS

Table 5.2 DISTRIBUTION OF RESPONDENTS AGE

\begin{tabular}{|l|l|l|}
\hline & FREQUENCY & PERCENTAGE \\
\hline $15-25$ & 92 & $26.7 \%$ \\
\hline $26-35$ & 196 & $57,0 \%$ \\
\hline $36-45$ & 43 & 13.0 \\
\hline 46 and above & 13 & 4.3 \\
\hline
\end{tabular}

From table 5.2 above, $57 \%$ of the respondents belong to $26-35$ age-group, $26.7 \%$ of the respondents fell within the age-group of 15-25, 43respondents making $13 \%$ belong to the 36-45 age-group, whereas 13 out of the total respondents fell into the age-group of 46 and above age-group.

The above frequency is presented on a pie chart as shown below:

\section{Age group}

- 15-25 - 26-35 - 36-45 46 and above

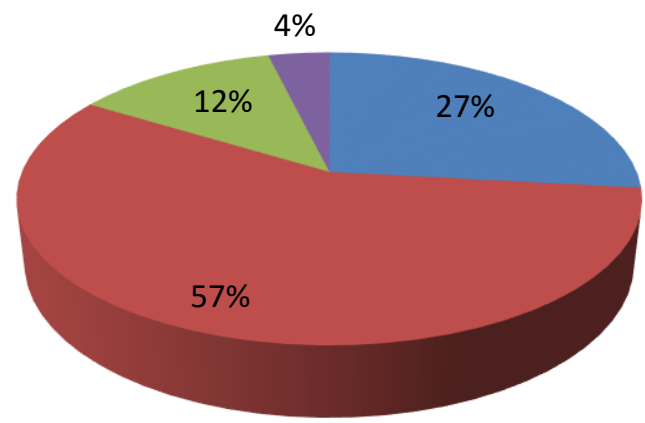




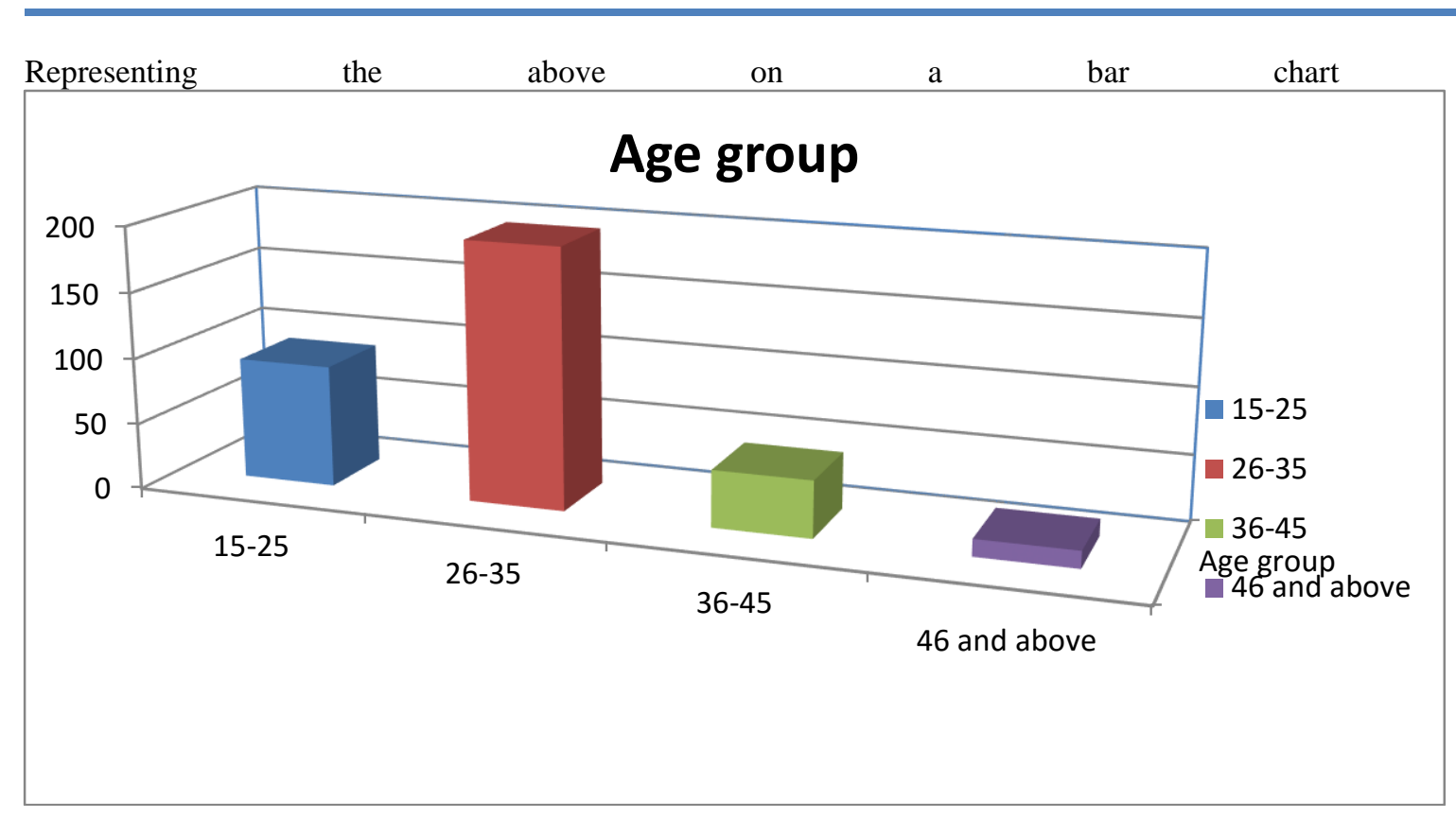

Fig 2: bar graph of distribution of respondents' Age

\subsection{DISTRIBUTION OF RESPONDENTS BY MARITAL STATUS Table 5.3 MARITAL STATUS}

\begin{tabular}{|l|l|l|}
\hline MARITAL STATUS & FREQUENCY & PERCENTAGE \\
\hline Married Living with Husband (MLWH) & 290 & $84.3 \%$ \\
\hline Married not Living with Husband (MNLWH) & 11 & $3.1 \%$ \\
\hline Divorced (D) & 5 & $1.5 \%$ \\
\hline Single (SG) & 28 & $8.1 \%$ \\
\hline Separated (SP) & 10 & $3 \%$ \\
\hline Total & 344 & \\
\hline
\end{tabular}

Table 5.3 above shows that $84.3 \%$ of the respondents are married women that are living with their husbands, followed by $8.1 \%$ of the respondents representing single mother, whereas, married women that are not living with their husbands, make up $3.1 \%$ of the respondents followed very closely by women that are separated from their husbands which are $3 \%$ and 5 women out of the 344 respondents are divorced and gave $1.5 \%$ Representing the above on a pie chart gives:

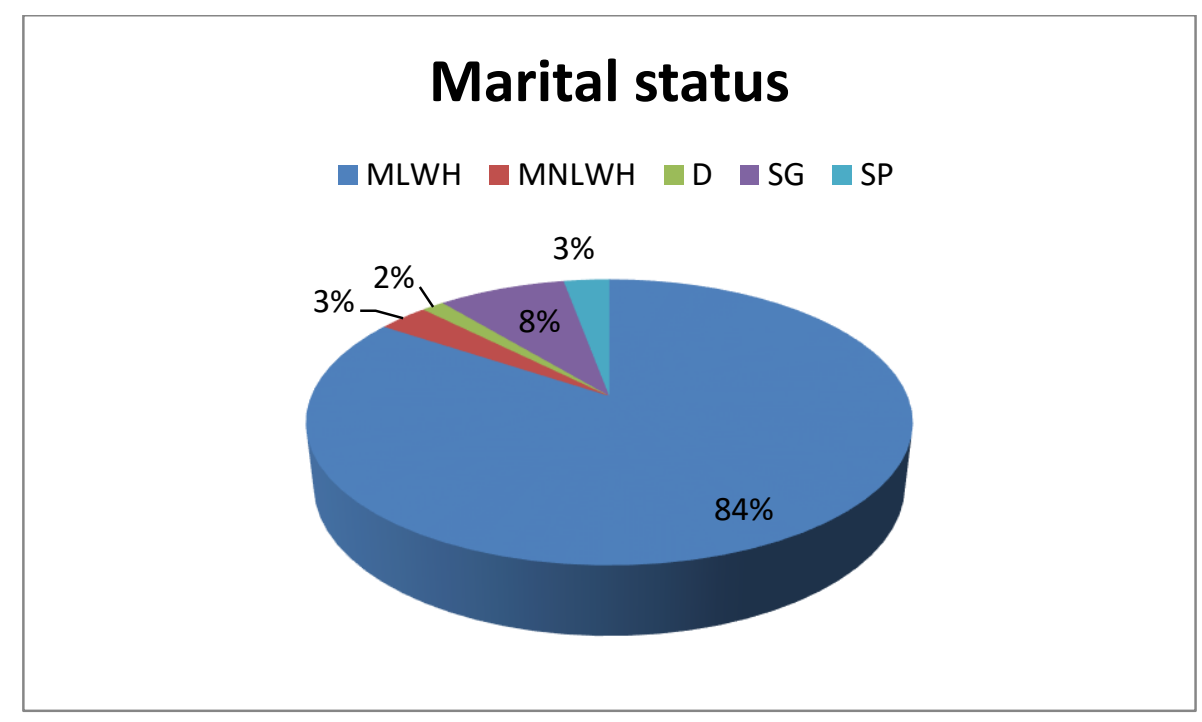

The bar chart of the above table gives: 


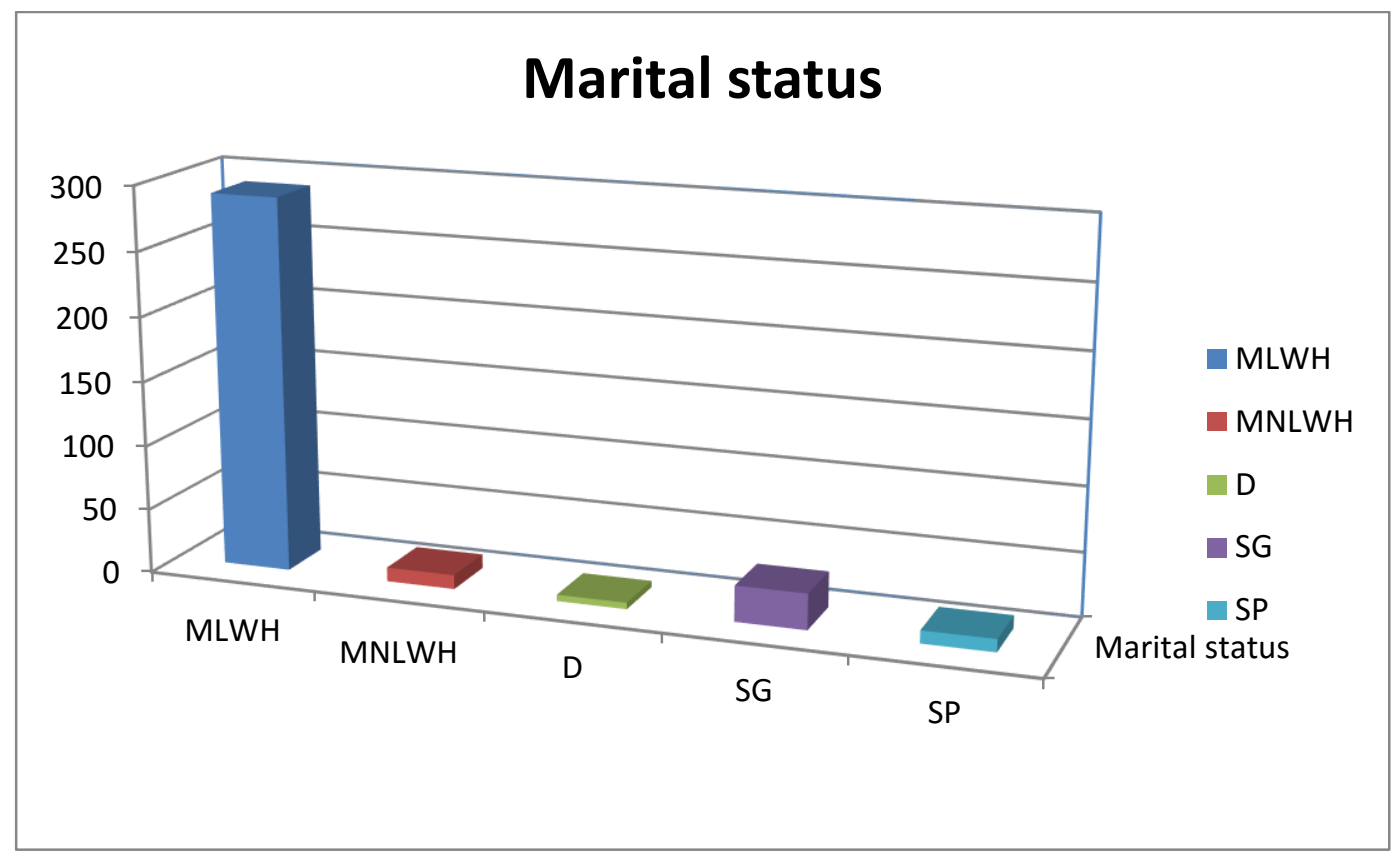

Fig 3: distribution of respondent Marital Status

5.4 DISTRIBUTION OF RESPONDENTS BY LEVEL OF EDUCATION
Table 5.4: EDUCATIONAL LEVEL OF RESPODENTS
\begin{tabular}{|l|l|l|}
\hline EDUCATIONAL LEVEL & FREQUENCY & PRCENTAGE \\
\hline Primary (P) & 9 & $2.6 \%$ \\
\hline Secondary (S) & 131 & $38 \%$ \\
\hline Tertiary (T) & 202 & $58.7 \%$ \\
\hline None (N) & 2 & $.6 \%$ \\
\hline Total & 344 & \\
\hline
\end{tabular}

Table 5.4 above shows that, pregnant mothers that have attained education up to tertiary level are $58 \%$ (i.e.202 out of $344)$, whereas, $38 \%$ of the respondents have secondary education. Also 9 out of the 344 pregnant women have primary education whereas 2 pregnant women out of the total respondents do not have any form of education $(0.6 \%)$ The pie chart of the above frequency gives:

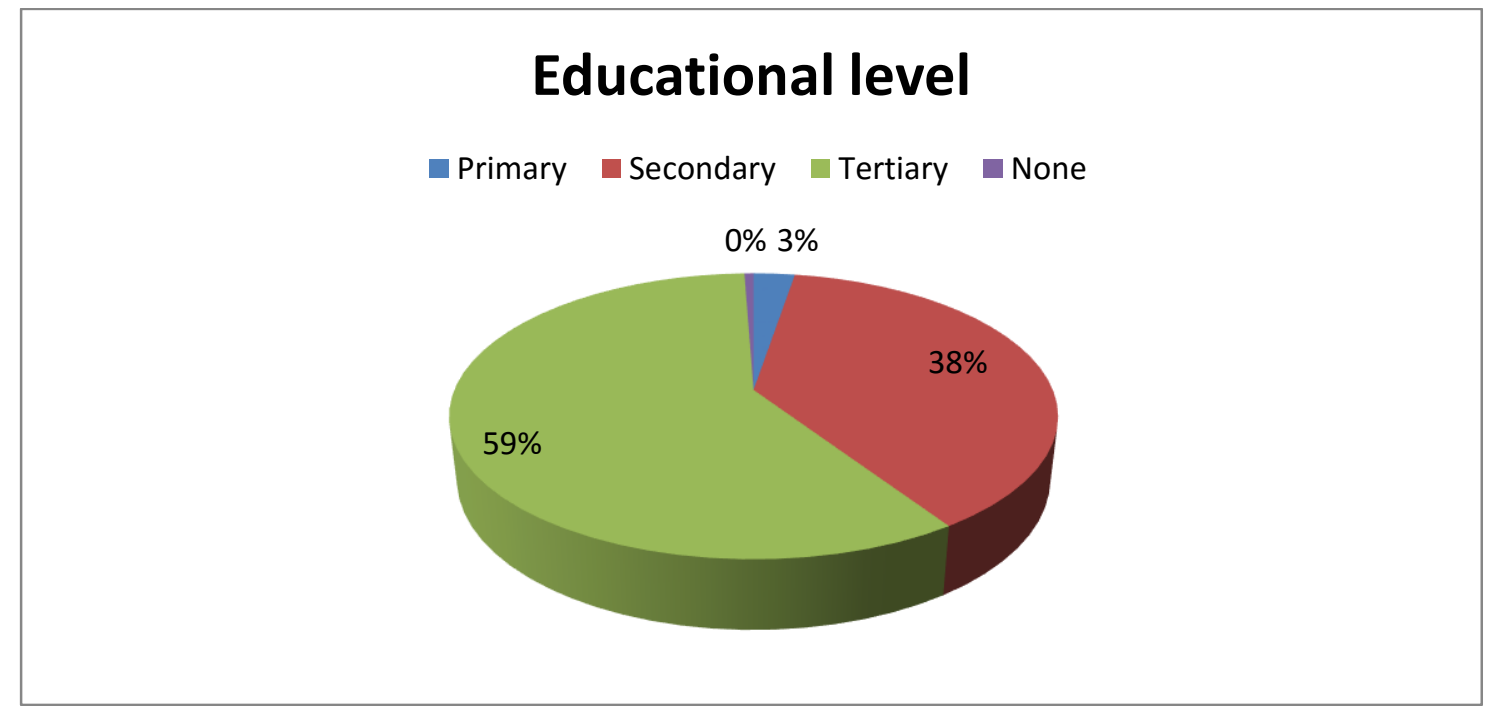

Presenting the above on a bar chart gives: 


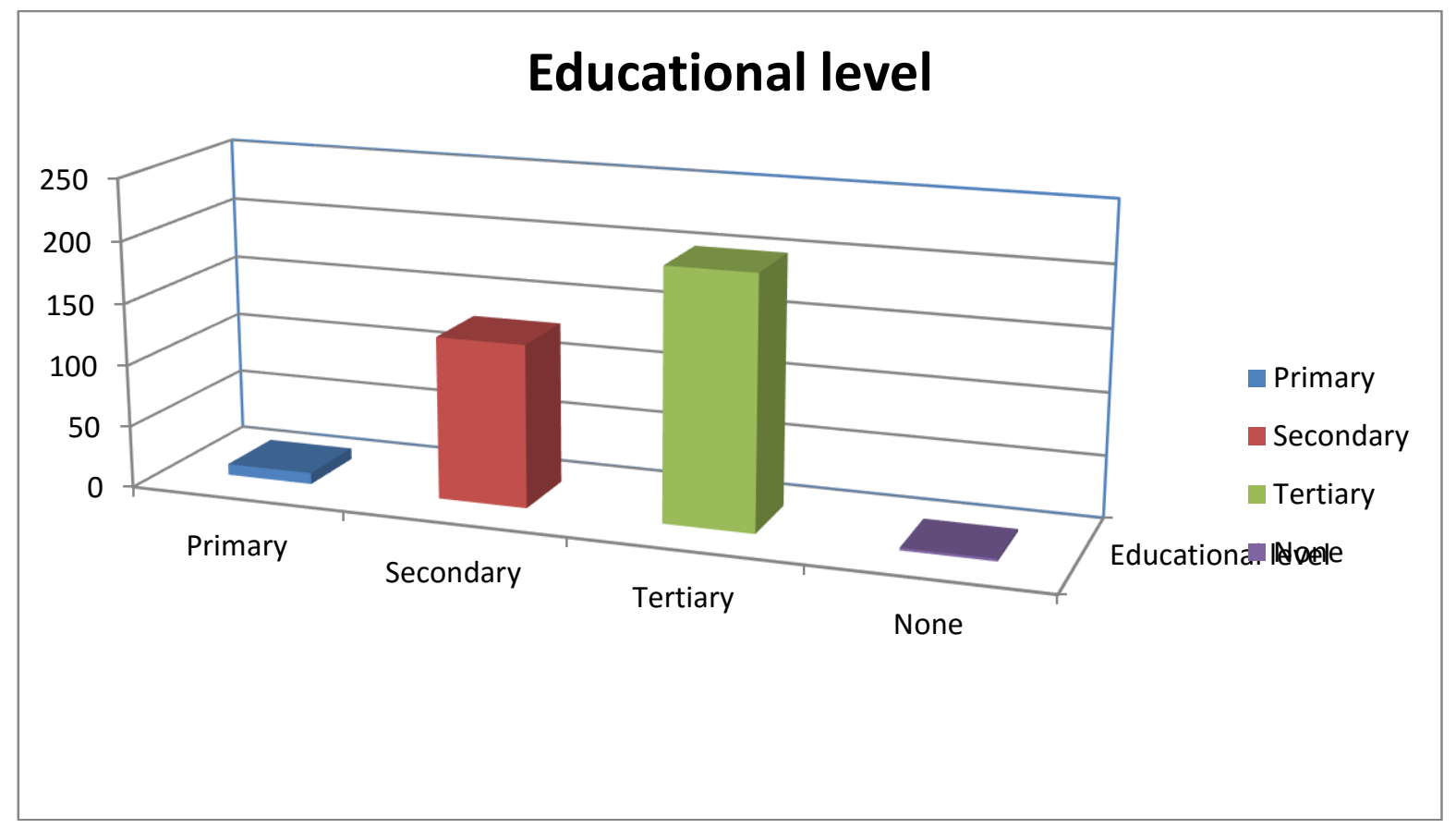

Fig 4: bar-graph of the respondents' Level of Education

DISTRIBUTION OF RESPODENTS BY RELIGION

Table 5.5: RELIGIOUS INCLINATION OF RESPONDENTS

\begin{tabular}{|l|l|l|}
\hline RELIGION & FREQUENCY & PERCENTAGE \\
\hline Christian catholic (CC) & 69 & $20 \%$ \\
\hline Christian Anglican (CA) & 81 & $24 \%$ \\
\hline Christian Pentecostal (CP) & 146 & $42 \%$ \\
\hline Other Christian Sect (OCS) & 25 & $7.3 \%$ \\
\hline Muslims (M) & 23 & $6.7 \%$ \\
\hline Total & 344 & \\
\hline
\end{tabular}

From table 5.5 above, 6.7\%(23 out of 344) of the respondents are Muslims, (25 out the 344) respondents make up $7.3 \%$ belong to Other Christian Sect given to $7.3 \%$ 20\% of the pregnant mothers are Catholics and 81(24\%) of the respondents are Anglicans, finally, 42\% (146 out of 344) attend Pentecostal church.

The pie chart of the above frequency gives:

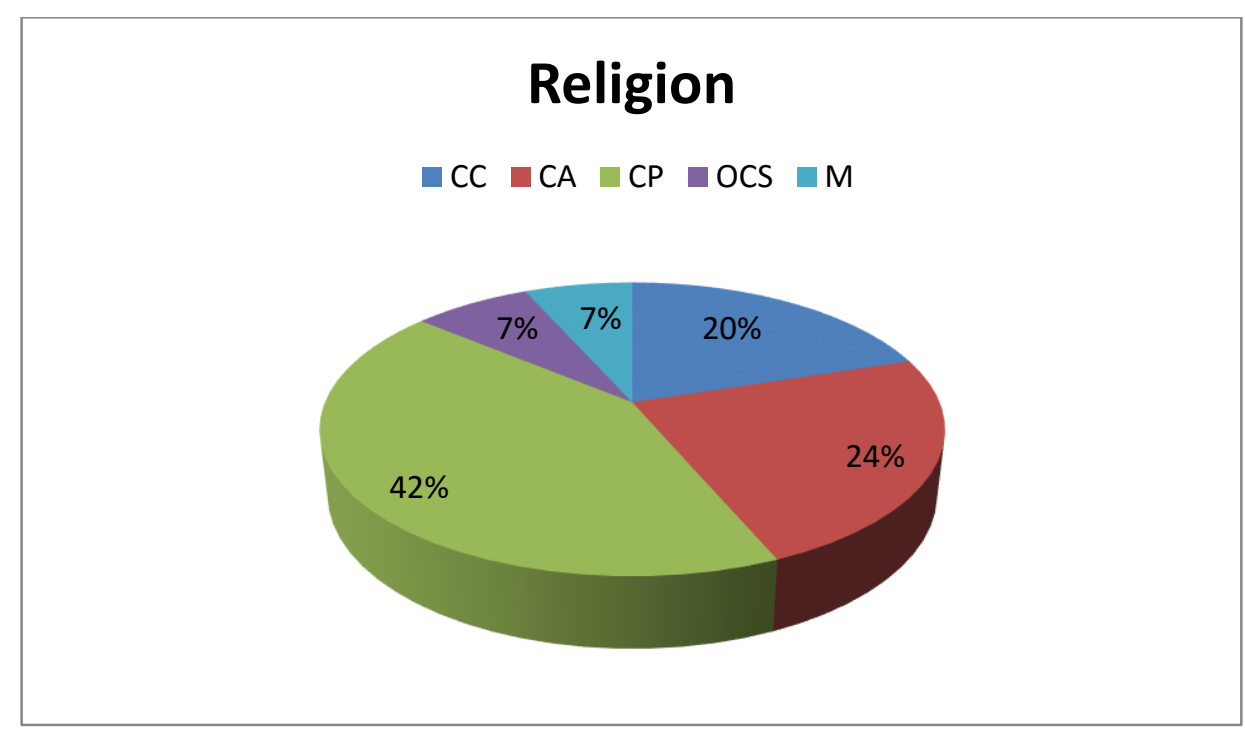


The bar chart of the above gives:

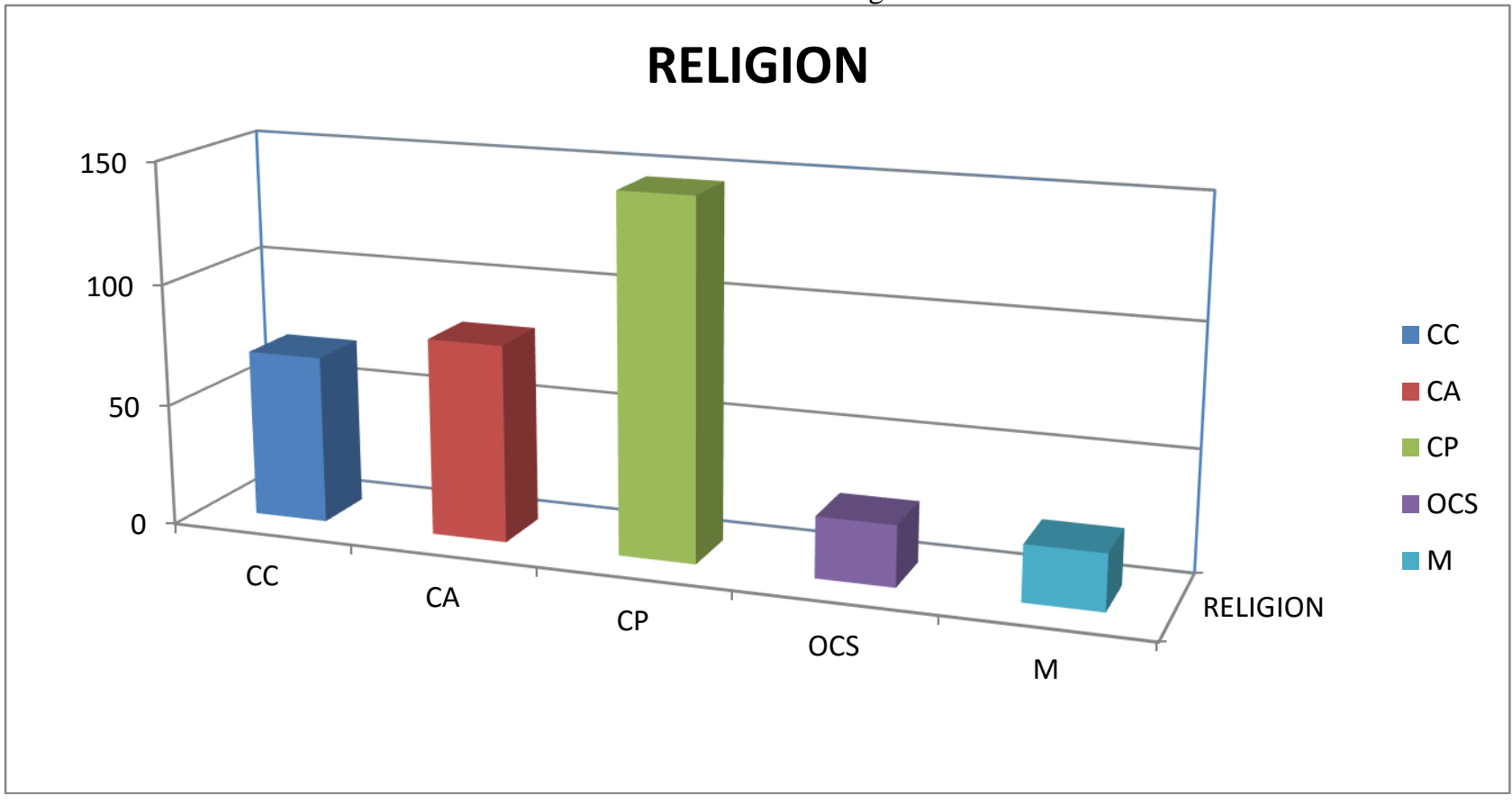

ig 5: bar graph of the respondents' distribution of Religion

5.6 DISTRIBUTION OF RESPONDENTS BY OCCUPATION

Table 5.6: DISTRIBUTION OF RESPONDENTS OCCUPATION

\begin{tabular}{|l|c|c|}
\hline PRIMARY OCCUPATION & FREQUENCY & PERCENTAGE \\
\hline House wife (HW) & 88 & $26 \%$ \\
\hline Civil/Public Servant (CPS) & 108 & $31 \%$ \\
\hline Self- Employed (SE) & 121 & $35 \%$ \\
\hline Professional (PROFF) & 27 & $8 \%$ \\
\hline Total & 344 & \\
\hline
\end{tabular}

Table 5.6 shows that, $35 \%$ (121 out of 344) of the respondents are self-employed, 108 out of 344 (31\%) of the pregnant women are Civil or Public Servants, 88 out of the 344(26\%) represents housewives, and $8 \%(27$ out of 344$)$ are professionals like doctors, engineers etc.

The pie chart of the above table gives:

\section{Primary occupation}

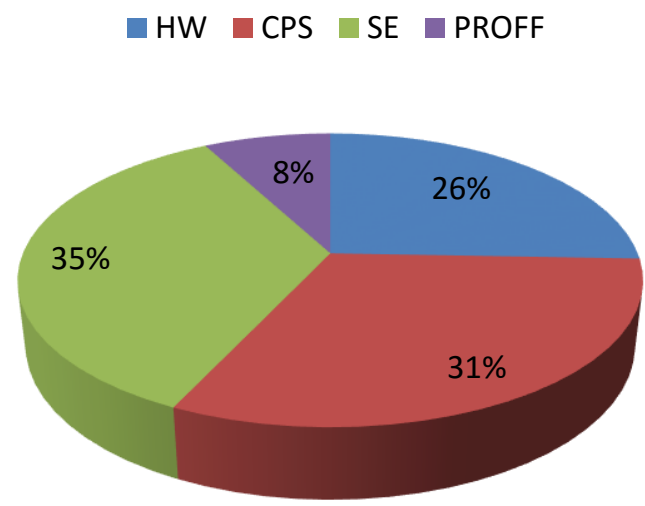

The above frequency is also represented in a bar graph below: 


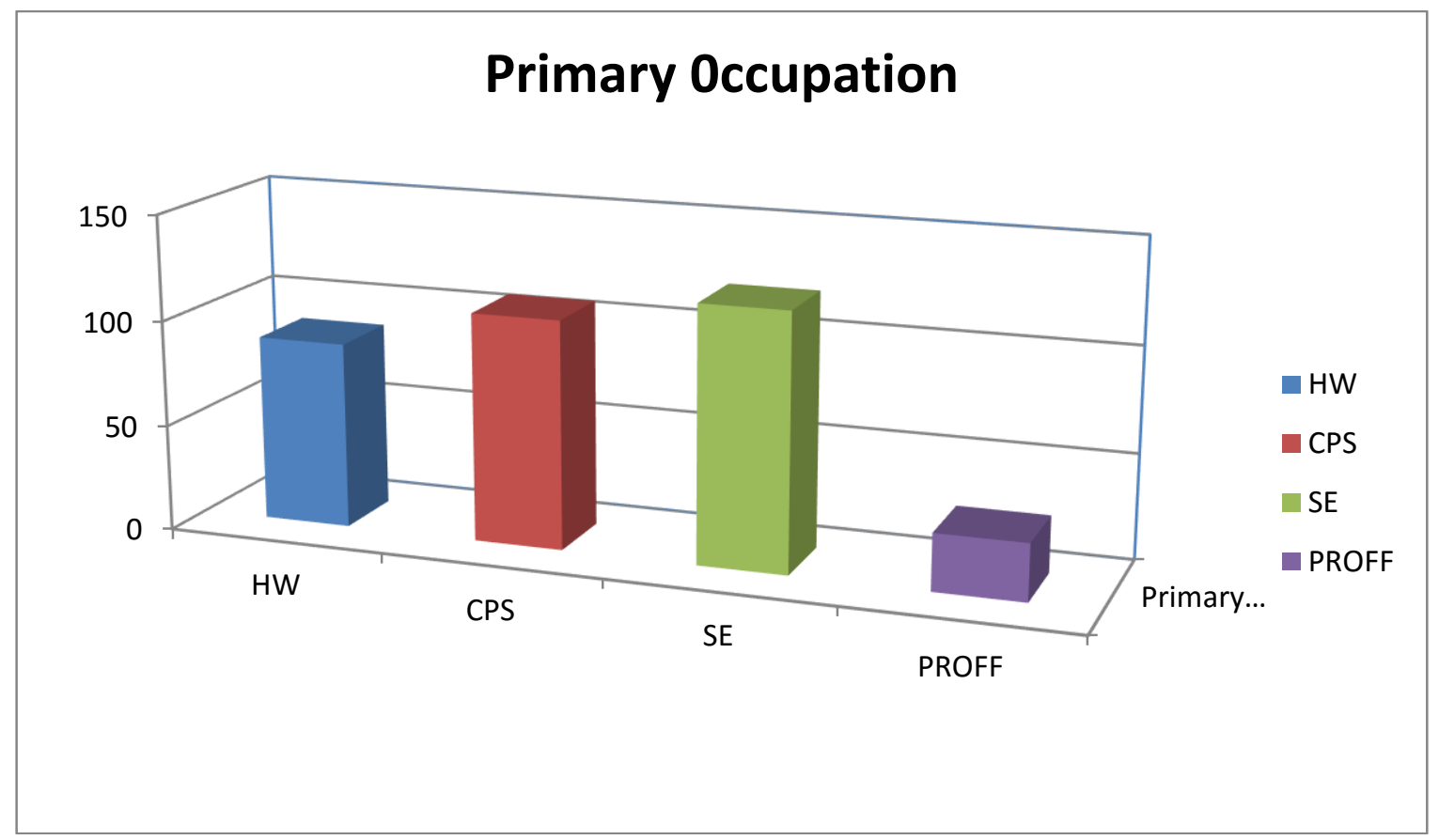

Fig 6: bar graph of the respondents' Occupation

\subsection{DISTRIBUTION OF RESPONDENTS BY LOCATION}

Table 5.7: LOCATION OF RESPONDENTS

\begin{tabular}{|l|l|l|}
\hline AREA & FREQUENCY & PERCENTAGE \\
\hline Urban Port Harcourt (UP) & 329 & $96 \%$ \\
\hline Rural Town (RT) & 15 & $4 \%$ \\
\hline Total & 344 & \\
\hline
\end{tabular}

The above table 5.7 shows that $4 \%$ (15 out of 344 ) of the respondents live in Rural area, whereas, 329 out of 344 $(95 \%)$ of the pregnant women live in Urban area.

The above table is presented in pie chart as shown below:

\section{Area of residence}

$\square \mathrm{UP} \backsim \mathrm{RT} \square \square$

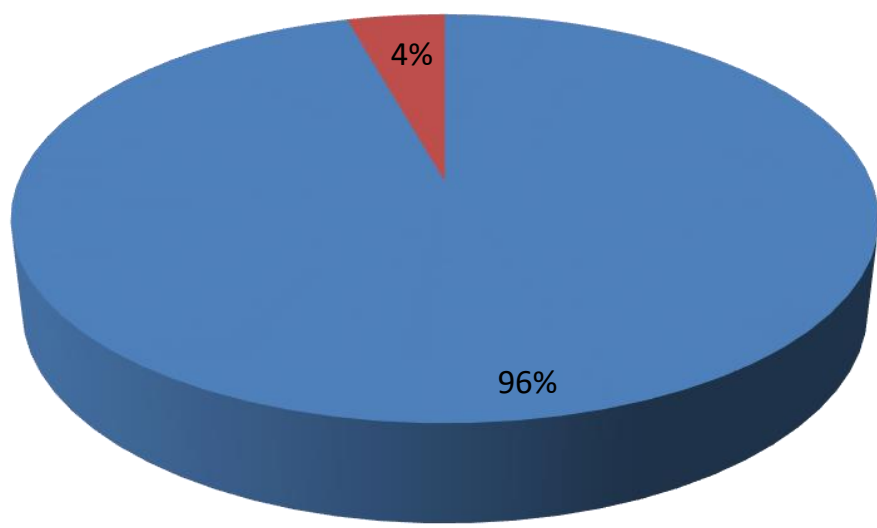


The above is also represented in a bar chart which gives:

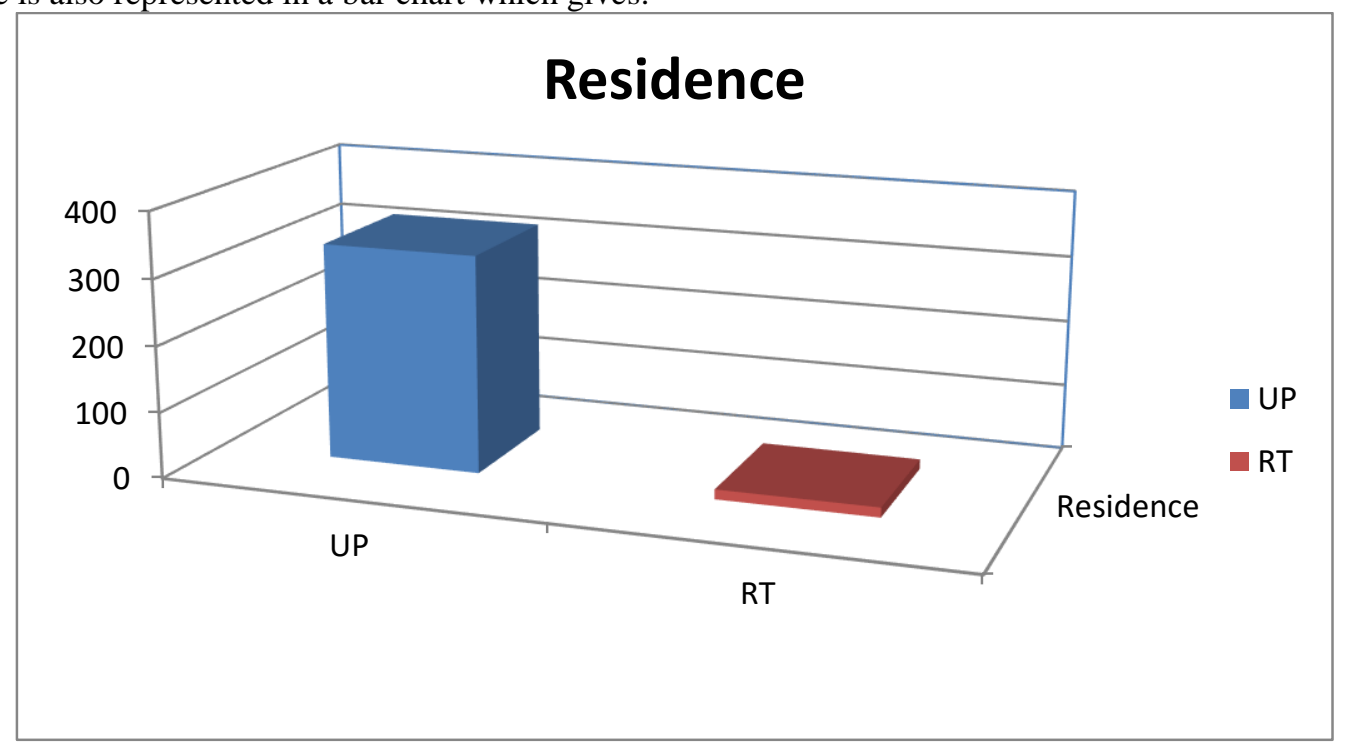

Fig 7: bar chart of respondents' Residence

D.8 TISTRIBUTION OF RESPONDENTS BY PARITY
\begin{tabular}{|l|l|l|}
\hline TUMIe 5.8 RESPONDENTS PARITY & PERCENTAGE \\
\hline$<1$ & FREQUENCY & $10 \%$ \\
\hline $1-2$ & 34 & $52 \%$ \\
\hline $3-4$ & 178 & $36 \%$ \\
\hline 5 and above & 125 & $2 \%$ \\
\hline Total & 7 & \\
\hline
\end{tabular}

7 out of $344(2 \%)$ of the pregnant mothers have at least five children as shown in table, 10\% (34 out of 344) of the respondents do not have children yet. 36\% (125 out of 344) of the respondents have between three or four children, whereas 178 out of $344(52 \%)$ have one or two children.

The pie chart of the above table gives:

\section{Respondent's Parity}

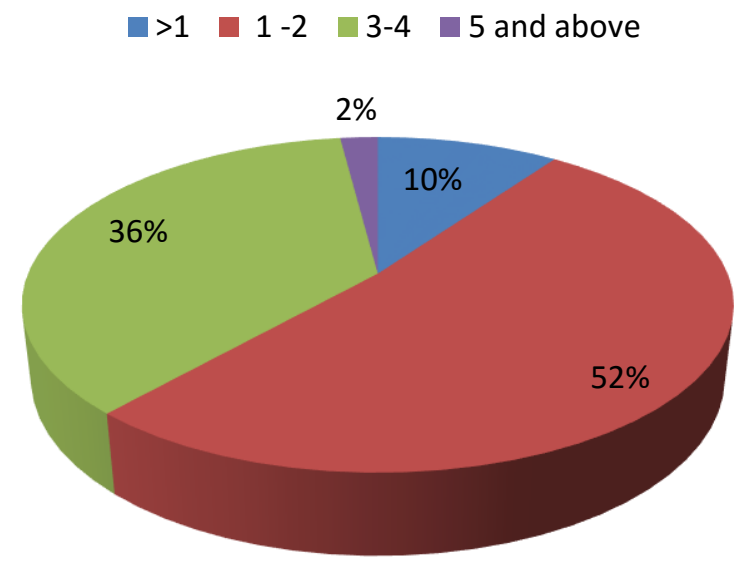

The above is also represented in a bar chart as shown below: 


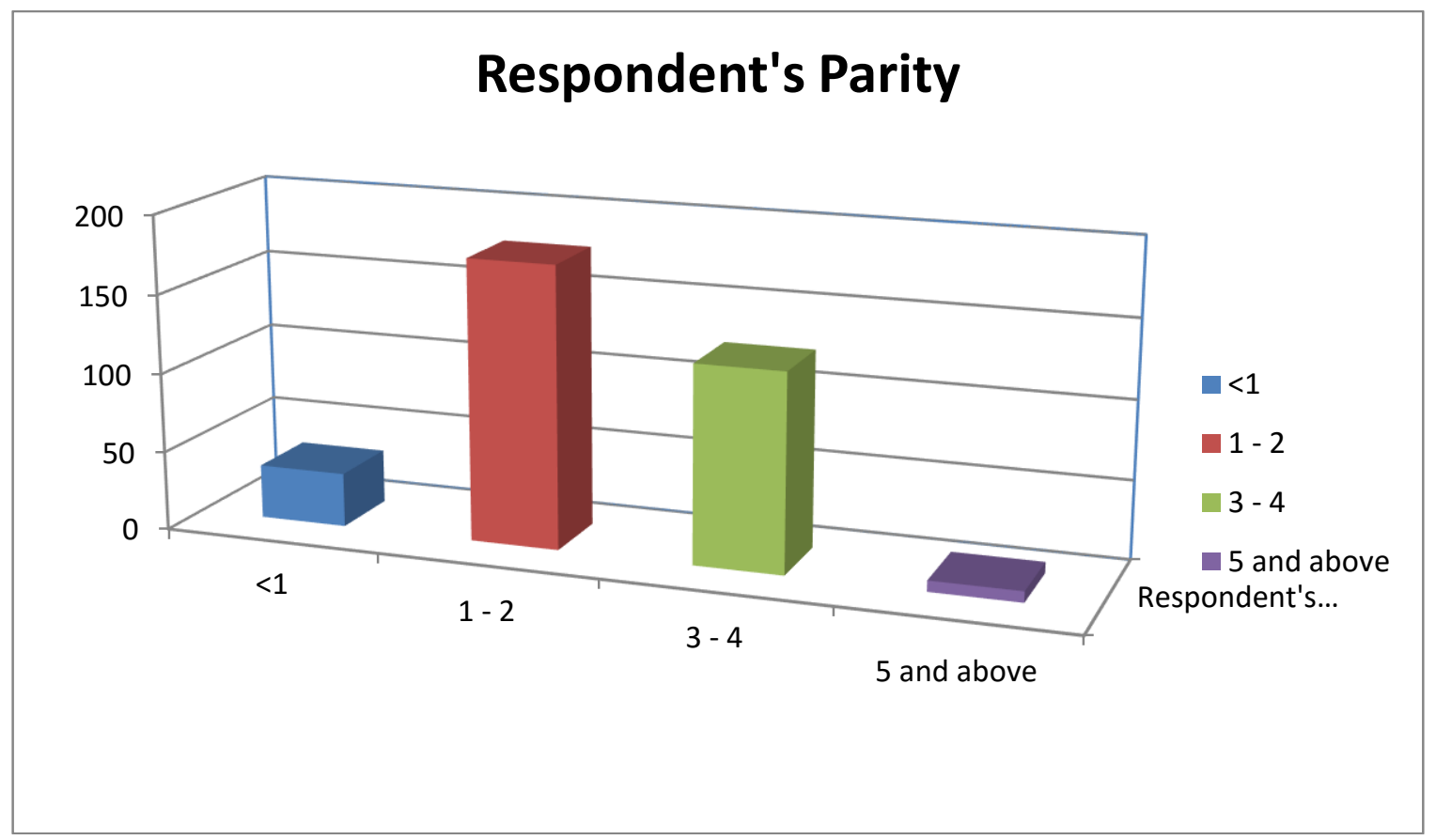

Fig 8: distribution of respondents Parity

5.9

\section{TEST OF HYPOTHESIS FOR LEVEL OF AWARENESS AND THEIR SOCIAL DEMOGRAPHIC VARIABLES}

$\left(\mathrm{H}_{0}\right)$ : There is no association between the level of awareness and their social demographic variables.

$\left(\mathrm{H}_{1}\right)$ : There is association between the level of awareness and their social demographic variables.

DECISION RULE: Reject the Null Hypothesis $\left(\mathrm{H}_{0}\right)$ if P-value is less than $\alpha=0.05$ (95\% level of significance) or reject $\mathrm{H}_{\mathrm{o}}$ if $\mathrm{X}_{\text {cal }}^{2}>\mathrm{X}_{(\mathrm{r}-1)(\mathrm{c}-1)}$ and accept if otherwise.

5.9.1 ANALYSIS TWO: INFLUENCE OF SOCIAL DEMOGRAPHIC VARIABLES ON LEVEL OF AWARENESS

TEST 1: AGE \& LEVEL OF AWARENESS

Table 5.9a: TEST ON AGE AND LEVEL OF AWARENESS

\begin{tabular}{|c|c|c|c|c|}
\hline \multirow{2}{*}{ 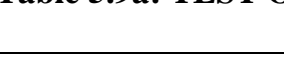 } & \multirow{2}{*}{\multicolumn{3}{|c|}{ LEVEL OF AWARENESS }} & \multirow{3}{*}{ Row Totals } \\
\hline & & & & \\
\hline AGE-GROUP & LOW & MODERATE & HIGH & \\
\hline $15-25$ & $\mathrm{O}_{\mathrm{i}}(1), \mathrm{E}_{\mathrm{i}}[0.53]$ & $\mathrm{O}_{\mathrm{i}}(1), \mathrm{E}_{\mathrm{i}}[3.21]$ & $\mathrm{E}_{\mathrm{i}}[88.28]$ & 92 \\
\hline $26-35$ & $\mathrm{O}_{\mathrm{i}}(1) \mathrm{E}_{\mathrm{i}}[1.14]$ & $\mathrm{O}_{\mathrm{i}}(6) \quad \mathrm{E}_{\mathrm{i}}[6.84]$ & $\mathrm{O}_{\mathrm{i}}(189) \quad \mathrm{E}_{\mathrm{i}}[188.02]$ & 196 \\
\hline $36-45$ & $\mathrm{O}_{\mathrm{i}}(0) \mathrm{E}_{\mathrm{i}}[0.25]$ & $\mathrm{O}_{\mathrm{i}}(3) \quad \mathrm{E}_{\mathrm{i}}[1.50]$ & $\mathrm{E}_{\mathrm{i}}[41.25]$ & 43 \\
\hline 46 and above & $\mathrm{O}_{\mathrm{i}}(0) \mathrm{E}_{\mathrm{i}}[0.08]$ & $\mathrm{O}_{\mathrm{i}}(2) \quad \mathrm{E}_{\mathrm{i}}[0.45]$ & $\mathrm{O}_{\mathrm{i}}(11) \quad \mathrm{E}_{\mathrm{i}}[12.47]$ & 13 \\
\hline Column Total & 2 & 12 & 330 & 344 \\
\hline
\end{tabular}

Table 5.9b: $X^{2}$ RESULT ON AGE AND LEVEL OF AWARENESS(spss output)

\begin{tabular}{|l|c|l|}
\hline Chi-square $\left(\mathrm{X}^{2}\right)$ value & Degree of freedom $(\mathrm{df})$ & P-value \\
\hline 9.3954 & 6 & 0.152529 \\
\hline
\end{tabular}

Test concerning Age and Level of awareness

\section{Hypothesis}

$\mathrm{H}_{0}$ : Age has no influence on Awareness vs $\mathrm{H}_{1}$ : Age has influence on Awareness

From the table $5.9 \mathrm{~b}$ above, $\mathrm{X}^{2}$ calculated at $2 \mathrm{df}=9.3952$, whereas $\mathrm{P}$-value $=0.152529$.

Decision Rule: Reject $\mathrm{H}_{\mathrm{o}}$ if $\mathrm{P}$-value $<0.05$.

Therefore, since P-value calculated (0.152529) > alpha level, we accept $\mathrm{H}_{\mathrm{o}}$ and conclude that age does not influences level of awareness. 
TEST 2: MARITAL STATUS AND LEVEL OF AWARENESS

Table 3.10a: $X^{2}$ TEST ON MARITAL STATUS AND LEVEL OF AWARENESS

\begin{tabular}{|c|c|c|c|c|}
\hline & LEVEL & AWARENESS & & \\
\hline MARITAL STATUS & LOW & MODERATE & HIGH & $\begin{array}{l}\text { Row } \\
\text { Total }\end{array}$ \\
\hline $\begin{array}{l}\text { Married and Living With } \\
\text { Husband }\end{array}$ & $\mathrm{O}_{\mathrm{i}}(0) \mathrm{E}_{\mathrm{i}}[1.69]$ & $\begin{array}{c}\mathrm{O}_{\mathrm{i}}(5) \\
\mathrm{E}_{\mathrm{i}}[10.12]\end{array}$ & $\mathrm{O}_{\mathrm{i}}(285) \mathrm{E}_{\mathrm{i}}[278.20]$ & 290 \\
\hline $\begin{array}{l}\text { Married and not Living With } \\
\text { Husband }\end{array}$ & $\mathrm{O}_{\mathrm{i}}(0) \mathrm{E}_{\mathrm{i}}[0.06]$ & $\mathrm{O}_{\mathrm{i}}(2) \quad \mathrm{E}_{\mathrm{i}}[0.38]$ & $\mathrm{O}_{\mathrm{i}}(9) \mathrm{E}_{\mathrm{i}}[10.55]$ & 11 \\
\hline Divorced & $\mathrm{O}_{\mathrm{i}}(1) \mathrm{E}_{\mathrm{i}}(0.03)$ & $\mathrm{O}_{\mathrm{i}}(2) \quad \mathrm{E}_{\mathrm{i}}[0.17]$ & $\mathrm{O}_{\mathrm{i}}(2) \mathrm{E}_{\mathrm{i}}[4.80]$ & 5 \\
\hline Single & $\mathrm{O}_{\mathrm{i}}(1) \mathrm{E}_{\mathrm{i}}[0.16]$ & $\mathrm{O}_{\mathrm{i}}(2) \quad \mathrm{E}_{\mathrm{i}}[0.98]$ & $\mathrm{O}_{\mathrm{i}}(25) \mathrm{E}_{\mathrm{i}}[26.86]$ & 28 \\
\hline Separated & $\mathrm{O}_{\mathrm{i}}(0) \mathrm{E}_{\mathrm{i}}[0.06]$ & $\mathrm{O}_{\mathrm{i}}(1) \quad \mathrm{E}_{\mathrm{i}}[0.35]$ & $\mathrm{O}_{\mathrm{i}}(9) \mathrm{E}_{\mathrm{i}}[9.59]$ & 10 \\
\hline Column Total & 2 & 12 & 330 & 344 \\
\hline
\end{tabular}

Table 5.10b: $X^{2}$ RESULT ON MARITAL STATUS AND LEVEL OF AWARENESS

\begin{tabular}{|l|c|l|}
\hline Chi-square $\left(\mathrm{X}^{2}\right)$ value & Degree of freedom $(\mathrm{df})$ & P-value \\
\hline 71.5243 & 8 & 0.00001 \\
\hline
\end{tabular}

Test concerning marital status and level of awareness

Hypothesis

$\mathrm{H}_{0}$ : Marital status has no influence on Awareness vs $\mathrm{H}_{1}$ : Marital status has influences on Awareness

From table $3.9 \mathrm{~b}$ above, $\mathrm{X}^{2}$ calculated at $8 \mathrm{df}=71.5243$, and $\mathrm{P}$-vale $=0.00001$

Decision Rule: Reject $\mathrm{H}_{\mathrm{o}}$ if $\mathrm{P}$-value $<0.05$

Since P-value $(0.00001)<$ alpha $=0.05$, we reject $\mathrm{H}_{0}$ and conclude that marital status influence HIV/AIDS level of awareness.

TEST 3: EDUCATION AND LEVEL OF WARENESS

Table 5.11a: $X^{2}$ TEST ON EDUCATION AND LEVEL OF AWEARNESS

\begin{tabular}{|l|c|c|c|l|}
\cline { 2 - 5 } \multicolumn{1}{c|}{} & \multicolumn{2}{c|}{ LEVEL OF AWARENESS } & \multicolumn{1}{c}{} \\
\hline EDU. LEVEL & LOW & MODERATE & HIGH & Row Total \\
\hline Primary & $\mathrm{O}_{\mathrm{i}}(0) \mathrm{E}_{\mathrm{i}}[0.05]$ & $\mathrm{O}_{\mathrm{i}}(1) \mathrm{E}_{\mathrm{i}}[0.31]$ & $\mathrm{O}_{\mathrm{i}}(8) \mathrm{E}_{\mathrm{i}}[8.63]$ & 9 \\
\hline Secondary & $\mathrm{O}_{\mathrm{i}}(1) \mathrm{E}_{\mathrm{i}}[0.76]$ & $\mathrm{O}_{\mathrm{i}}(6) \mathrm{E}_{\mathrm{i}}[4.57]$ & $\mathrm{O}_{\mathrm{i}}(124) \mathrm{E}_{\mathrm{i}}[125.67]$ & 131 \\
\hline Tertiary & $\mathrm{O}_{\mathrm{i}}(1) \mathrm{E}_{\mathrm{i}}[1.17]$ & $\mathrm{O}_{\mathrm{i}}(3) \mathrm{E}_{\mathrm{i}}[7.05]$ & $\mathrm{O}_{\mathrm{i}}(198) \mathrm{E}_{\mathrm{i}}[193.78]$ & 202 \\
\hline None & $\mathrm{O}_{\mathrm{i}}(0) \mathrm{E}_{\mathrm{i}}[0.01]$ & $\mathrm{O}_{\mathrm{i}}(2) \mathrm{E}_{\mathrm{i}}[0.07]$ & $\mathrm{O}_{\mathrm{i}}(0) \mathrm{E}_{\mathrm{i}}[1.92]$ & 2 \\
\hline Column Total & 2 & 12 & 330 & 344 \\
\hline
\end{tabular}

Table 3.11b: $X^{2}$ RESULT ON EDUCATION AND LEVEL OF AWARENESS

\begin{tabular}{|l|c|l|}
\hline Chi-square $\left(\mathrm{X}^{2}\right)$ value & Degree of freedom $(\mathrm{df})$ & P-value \\
\hline 59.9173 & 8 & 0.00001 \\
\hline
\end{tabular}

Test concerning Education and Level of Awareness

Hypothesis

$\mathrm{H}_{0}$ : Education has no influence on Awareness vs $\mathrm{H}_{1}$ : Education has influence on Awareness

From table $3.10 \mathrm{~b}$ above, the calculated $\mathrm{X}^{2}$ at $8 \mathrm{df}=59.9173$ and $\mathrm{P}$-value $=0.00001$.

Decision Rule: Reject $\mathrm{H}_{\mathrm{o}}$ if $\mathrm{P}$-value $<0.05$

Since the result show that $\mathrm{P}$-value $(0.0001)<$ alpha $=0.05$, we reject $\mathrm{H}_{0}$ and conclude that education has influence on the level of awareness of HIV/AIDS

TEST 4: RELIGION AND LEVEL OF AWARENESS

Table 5.12a: $X^{2}$ TEST ON RELIGION AND LEVEL OF AWARENESS

\begin{tabular}{|l|c|c|l|l|}
\cline { 2 - 4 } \multicolumn{1}{c|}{} & \multicolumn{2}{c|}{ LEVEL OF AWARENESS } & \multicolumn{1}{c}{ Row Total } \\
\hline RELIGION & LOW & MODERATE & $\mathrm{O}_{\mathrm{i}}(66) \mathrm{E}_{\mathrm{i}}[68.19]$ & 69 \\
\hline $\begin{array}{l}\text { Christian } \\
\text { Catholic }\end{array}$ & $\mathrm{O}_{\mathrm{i}}(0) \mathrm{E}_{\mathrm{i}}[0.04]$ & $\mathrm{O}_{\mathrm{i}}(3) \mathrm{E}_{\mathrm{i}}[2.41]$ & & \\
\hline
\end{tabular}




\begin{tabular}{|l|l|l|l|l|}
\hline $\begin{array}{l}\text { Christian } \\
\text { Anglican }\end{array}$ & $\mathrm{O}_{\mathrm{i}}(1) \mathrm{E}_{\mathrm{i}}[0.47]$ & $\mathrm{O}_{\mathrm{i}}(3) \mathrm{E}_{\mathrm{i}}[2.83]$ & $\mathrm{O}_{\mathrm{i}}(77) \mathrm{E}_{\mathrm{i}}[77.70]$ & 81 \\
\hline $\begin{array}{l}\text { Christian } \\
\text { Pentecostal }\end{array}$ & $\mathrm{O}_{\mathrm{i}}(1) \mathrm{E}_{\mathrm{i}}[0.85]$ & $\mathrm{O}_{\mathrm{i}}(5) \mathrm{E}_{\mathrm{i}}[5.09]$ & $\mathrm{O}_{\mathrm{i}}(141) \mathrm{E}_{\mathrm{i}}[140.06]$ & 146 \\
\hline $\begin{array}{l}\text { Other Christian } \\
\text { sect. }\end{array}$ & $\mathrm{O}_{\mathrm{i}}(0) \mathrm{E}_{\mathrm{i}}[0.15]$ & $\mathrm{O}_{\mathrm{i}}(1) \mathrm{E}_{\mathrm{i}}[0.87]$ & $\mathrm{O}_{\mathrm{i}}(24) \mathrm{E}_{\mathrm{i}}[23.98]$ & 25 \\
\hline Muslims & $\mathrm{O}_{\mathrm{i}}(0) \mathrm{E}_{\mathrm{i}}[0.13]$ & $\mathrm{O}_{\mathrm{i}}(1) \mathrm{E}_{\mathrm{i}}[0.80]$ & $\mathrm{O}_{\mathrm{i}}(22) \mathrm{E}_{\mathrm{i}}[22.08]$ & 23 \\
\hline Column Total & 2 & 12 & 330 & 344 \\
\hline
\end{tabular}

Table 5.12b: $\mathrm{X}^{2}$ RESULT ON RELIGION AND LEVEL OF AWARENESS

\begin{tabular}{|l|c|l|}
\hline Chi-square $\left(\mathrm{X}^{2}\right)$ value & Degree of freedom $(\mathrm{df})$ & P-value \\
\hline 1.7739 & 8 & 0.987176 \\
\hline
\end{tabular}

Test concerning Religion and Level of Awareness

Hypothesis

$\mathrm{H}_{0}$ : Religion has no influence on awareness vs $\mathrm{H}_{1}$ : religion has influence on Awareness

From table $3.11 \mathrm{~b}$ as shown above, the calculated $\mathrm{X}^{2}$ at $8 \mathrm{df}=1.7739$ and $\mathrm{P}$-value $=0.987176$

Therefore, since P-value $(0.987176)>$ alpha $=0.05$, accept $\mathrm{H}_{0}$ and conclude that religion has nothing to with HIV/AIDS level of awareness.

TEST 5: OCCUPATION AND LEVEL OF AWARENESS

Table 5.13a: $X^{2}$ TEST ON OCCUPATION AND LEVEL OF AWARENESS

\begin{tabular}{|l|c|c|l|l|}
\cline { 2 - 5 } \multicolumn{1}{c|}{ LEVEL OF AWARENESS } & \multicolumn{1}{l}{} \\
\hline OCCUPATION & LOW & MODERATE & HIGH & Row Total \\
\hline House Wives & $\mathrm{O}_{\mathrm{i}}(1) \mathrm{E}_{\mathrm{i}}[0.51]$ & $\mathrm{O}_{\mathrm{i}}(2) \mathrm{E}_{\mathrm{i}}[3,07]$ & $\mathrm{O}_{\mathrm{i}}(85)_{\mathrm{i}}[84.42]$ & 88 \\
\hline Civil/Public Servants & $\mathrm{O}_{\mathrm{i}}(0) \mathrm{E}_{\mathrm{i}}[0.63]$ & $\mathrm{O}_{\mathrm{i}}(2) \mathrm{E}_{\mathrm{i}}[3.77]$ & $\mathrm{O}_{\mathrm{i}}(106) \mathrm{E}_{\mathrm{i}}[103.60]$ & 108 \\
\hline Self Employed & $\mathrm{O}_{\mathrm{i}}(1) \mathrm{E}_{\mathrm{i}}[0.70]$ & $\mathrm{O}_{\mathrm{i}}(7) \mathrm{E}_{\mathrm{i}}[4.33]$ & $\mathrm{O}_{\mathrm{i}}(113) \mathrm{E}_{\mathrm{i}}[116.08]$ & 121 \\
\hline Professionals & $\mathrm{O}_{\mathrm{i}}(0) \mathrm{E}_{\mathrm{i}}[0.16]$ & $\mathrm{O}_{\mathrm{i}}(1) \mathrm{E}_{\mathrm{i}}(0.95)$ & $\mathrm{O}_{\mathrm{i}}(26) \mathrm{E}_{\mathrm{i}}[25.90]$ & 27 \\
\hline Column Total & 2 & 12 & 330 & 344 \\
\hline
\end{tabular}

Table 5.13b: $\mathrm{X}^{2}$ RESULT ON OCCUPATION AND LEVEL OF AWARENESS

\begin{tabular}{|l|c|l|}
\hline Chi-square $\left(\mathrm{X}^{2}\right)$ value & Degree of freedom $(\mathrm{df})$ & P-value \\
\hline 4.5526 & 6 & 0.602335 \\
\hline
\end{tabular}

Test concerning Occupation and Level of Awareness

Hypothesis

$\mathrm{H}_{0}$ : Occupation does not influence awareness level vs $\mathrm{H}_{1}$ : Occupation has influence on awareness level

From table $3.12 \mathrm{~b}$ above, $\mathrm{X}^{2}$ calculated at $6 \mathrm{df}=4.5526$ and $\mathrm{P}$-value $=0.602335$.

Decision Rule: reject $\mathrm{H}_{\mathrm{o}}$ if $\mathrm{P}$-value $<0.05$

Since the result shows that P-value $(0.602335)>$ alpha $=0.05$, it implies that occupation does not have influence on the level of awareness of HIV/AIDS, therefore we accept $\mathrm{H}_{0}$.

TEST 6: LOCATION AND LEVEL OF AWARENESS

Table 3.14a: $\mathrm{X}^{2}$ TEST ON LOCATON AND LEVEL OF AWARENESS

\begin{tabular}{|l|l|l|l|l|}
\cline { 2 - 4 } \multicolumn{1}{c|}{} & \multicolumn{2}{c|}{ LEVEL OF AWARENESS } & \multicolumn{1}{l}{} \\
\hline AREA & LOW & MODERATE & HIGH & Row Total \\
\hline Urban Town & $\mathrm{O}_{\mathrm{i}}(2)$ & $\mathrm{O}_{\mathrm{i}}(11)$ & $\mathrm{O}_{\mathrm{i}}(316)$ & 329 \\
& $\mathrm{E}_{\mathrm{i}}[1.91]$ & $\mathrm{E}_{\mathrm{i}}[11,48]$ & $\mathrm{E}_{\mathrm{i}}[315.18]$ & \\
\hline Rural Town & $\mathrm{O}_{\mathrm{i}}(0)$ & $\mathrm{O}_{\mathrm{i}}(1)$ & $\mathrm{O}_{\mathrm{i}}(14)$ & 15 \\
& $\mathrm{E}_{\mathrm{i}}[0.09]$ & $\mathrm{E}_{\mathrm{i}}[0.52]$ & $\mathrm{E}_{\mathrm{i}}[14.30]$ & \\
\hline Column Total & 2 & 12 & 330 & 344 \\
\hline
\end{tabular}

Table 5.14b: X2 RESULT ON RESIDENCE AND LEVEL OF AWARENESS

\begin{tabular}{|l|c|l|}
\hline Chi-square $(\mathrm{X} 2)$ value & Degree of freedom $(\mathrm{df})$ & P-value \\
\hline 0.5564 & 2 & 0.757152 \\
\hline
\end{tabular}

Test concerning Residence and level of Awareness

Hypothesis

$\mathrm{H}_{0}$ : Environment has no influence on Awareness level vs $\mathrm{H}_{1}$ : Environment has influence on Awareness level 
From table $3.13 \mathrm{~b}$ above, the $\mathrm{X}^{2}$ calculated at $2 \mathrm{df}=0.5564$ and $\mathrm{P}$-value $=0.757152$.

Decision Rule: Reject $\mathrm{H}_{\mathrm{o}}$ if $\mathrm{P}$-value $<0.05$

The result shows that P-value $(0.757152)>$ alpha $=0.05$, therefore we accept the Null Hypothesis $\left(\mathrm{H}_{\mathrm{o}}\right)$ and conclude that residence does not influence HIV/AIDS level of awareness.

TEST 7: PARITY AND LEVEL OF AWRENESS

Table 5.15a: $X^{2}$ TEST ON PARITY AND LEVEL OF AWARENESS

\begin{tabular}{|l|c|c|c|l|}
\cline { 2 - 4 } \multicolumn{1}{l|}{} & \multicolumn{2}{l|}{ LEVEL OF AWARENESS } & \multicolumn{1}{l}{} \\
\hline N0.OF CHILDREN & LOW & MODERATE & HIGH & Row Total \\
\hline$<1$ & $\mathrm{O}_{\mathrm{i}}(1) \mathrm{E}_{\mathrm{i}}[0.20]$ & $\mathrm{O}_{\mathrm{i}}(2) \quad \mathrm{E}_{\mathrm{i}}[1.19]$ & $\mathrm{O}_{\mathrm{i}}(31) \mathrm{E}_{\mathrm{i}}[32.62]$ & 34 \\
\hline $1-2$ & $\mathrm{O}_{\mathrm{i}}(1) \mathrm{E}_{\mathrm{i}}[1.03]$ & $\mathrm{O}_{\mathrm{i}}(3) \mathrm{E}_{\mathrm{i}}[0.21]$ & $\mathrm{O}_{\mathrm{i}}(174) \mathrm{E}_{\mathrm{i}}[170.76]$ & 178 \\
\hline $3-4$ & $\mathrm{O}_{\mathrm{i}}(0) \mathrm{E}_{\mathrm{i}}[0.73]$ & $\mathrm{O}_{\mathrm{i}}(4) \mathrm{E}_{\mathrm{i}}[4.36]$ & $\mathrm{O}_{\mathrm{i}}(121) \mathrm{E}_{\mathrm{i}}[119.91]$ & 125 \\
\hline 5 and above & $\mathrm{O}_{\mathrm{i}}(0) \mathrm{E}_{\mathrm{i}}[0.04]$ & $\mathrm{O}_{\mathrm{i}}(3) \mathrm{E}_{\mathrm{i}}[0.24]$ & $\mathrm{O}_{\mathrm{i}}(4) \mathrm{E}_{\mathrm{i}}[6.72]$ & 7 \\
\hline Column Total & 2 & 12 & 330 & 344 \\
\hline
\end{tabular}

Table 5.15b: $\mathrm{X}^{2}$ RESULT OF PARITY ON LEVEL OF AWARENESS

\begin{tabular}{|l|c|l|}
\hline Chi-square $\left(\mathrm{X}^{2}\right)$ value & Degree of freedom & P-value \\
\hline 38.623 & 6 & 0.00001 \\
\hline
\end{tabular}

Test concerning Parity and Level of Awareness

Hypothesis

$\mathrm{H}_{0}$ : Parity has no influence on awareness vs $\mathrm{H}_{1}$ : Parity has influence on awareness

From table $3.13 \mathrm{~b}$ above, $\mathrm{X}^{2}$ calculated at $6 \mathrm{df}=38.623$ and $\mathrm{P}$-value $=0.00001$.

Decision Rule: Reject $\mathrm{H}_{\mathrm{o}}$ if $\mathrm{P}$-value $<0.05$

Since P-value $(0.00001)<$ alpha $=0.05$, we reject $\mathrm{H}_{\mathrm{o}}$ and conclude that Parity influences the level of awareness of HIV/AIDS

\subsection{SUMMARY}

The study utilized $98.3 \%$ of the questionnaires that were administered to the respondents. From table 3.1, it is seen that $95.93 \%$ of the respondents have high level of awareness, $3.48 \%$ of them are moderately aware, whereas $0.58 \%$ of the total respondents have low level of HIV/AIDS awareness.

It was also observed that $57 \%$ of the respondents fell within the active reproductive age group $26-35$ as shown in table 3.2 , also $84 \%$ of the respondent as shown in table 3.3 are living with their husbands. Table 5.4 shows that $59 \%$ of them attained tertiary level of education, table 5.5 shows that $93.3 \%$ of the respondents are predominantly Christians. 121 out of the 344 respondent as shown in table 5.6 are selfemployed. Most of the respondents precisely $96 \%$ live in urban area as stated in table 3.7, whereas it observed in table 5.8 that $52 \%$ of the respondent have at least 1 child.

The study showed that majority of the respondents have high level of awareness on HIV/AIDS, a total of $330(96 \%)$ out of 344 were found to be very aware of HIV/AIDS

However, regarding the influence of sociodemographic variables on level of awareness, this study could not establish any evidence of the influence of Age, Religion, Occupation, and Residence on the respondents' level of HIV/AIDS awareness as shown in table $3.8 \mathrm{a} \& \mathrm{~b}$, table $5.12 \mathrm{a} \& \mathrm{~b}$, table $5.13 \mathrm{a} \& \mathrm{~b}$, and table $5.114 \mathrm{a} \& \mathrm{~b}$ respectively.

On the other hand, the study established evidence of the influence of Marital status, Education and Parity on the respondents' level of HIV/AIDS awareness as shown in table 5.10a\&b, table 5.11a\&b, and table $5.12 \mathrm{a} \& \mathrm{~b}$ respectively.

\section{CONCLUSION}

The awareness level of HIV/AIDS is high among pregnant women in Port Harcourt, Rivers State. Important observations made in this study are that Marital status, Educational level and Parity have an influence on the respondents' level of awareness of the disease, whereas, Age, Religious inclination, Occupation and Residence have no influence on the respondent's level of awareness.

\section{References}

1. Adekanle,O., Ndububa,D.A., Ayodeji,O.O., Paul-Odo,B. and Folorunso, T.A.(2010). Sexual Transmission of the Hepatitis B Virus among blood donors in a tertiary hospital in Nigeria. Singapore Med J; 51:944-7.

2. Adeleke,S.I., Mukhtar-Yola,M., Gwarzo,G.D. (2009). Awareness and knowledge of mothers attending the pediatric HIV clinic, Kano, Nigeria. Annals of African Medicine. (4) 210-214

3. Bala, S (2013). High HIV Prevalence in Rivers State. Available onhttp://www.thisdaylive.com/articles/in-a-newsurvey-nigeria-s-hiv-aids-prevalence-drops-to-3-4/166023/06/12/2013.

4. Bang, R. and Bang, A. (1989). “A community study of ynecological diseases in Indian villages in Zeidenstein and 
Moore" (eds.) learning about Sexuality: A Practical Beginning, New York: Population Council.

5. Baral, S., Beyrer, C., Muessig, K., Poteat, T., Wirtz, A.L., Decker, M.R.,... Kerrigan,D.(2012). Burden of HIV among female sex workers in low-income and middle-income countries: A systematic review and meta-analysis. Lancet Infectious Diseases, 12(7): 538-549.

6. Behets,F.I, Matendo, R., Vaz, M.E., Kilese, N., Nanlele, D. \& Kokolomami, J., (2008). Preventing vertical transmission of HIV in Kinshasa, Democratic Republic of the Congo: A baseline survey of 18 antenatal clinics. Bull World Health Organ; 24:969-75.

7. Centers for Disease Control (2005). HIV/AIDS surveillance report, 2004 Atlanta, US department of health and human services, $\quad C D C$, (16) 1-46. Available on: www.cdc.gov/hiv/topics.

8. Cohen, M.,Chen, Y.Q., Macauley, M.,Gamble,T.,Hakim,J. \& Kumwenda, J. (2011). Prevention of HIV-1 infection with early antiretroviral therapy. New England Journal of Medicine, 365: 493-505.

9. Connor, E.M., Sperling R.F. \& Gelber R. (1994). The Pediatric AIDS clinical trials group Protocol 076 Study group. Prevention of Maternal-Infant transmission of HIV type 1 with Zidovudine treatment. New England Journal Med. 331: 11731180.

10. Damania, K.R and Tank, P.D.(2006). Prevention of Mother to Child Transmission of HIV Infection. J. Obstet Gynecol India 56(5):390-395

11. Daniel,O.J., Salako, A.A., Oluwole,F.A. and Oladapo O.T., (2004). HIV Duran,A.S., Ivalo,S.A., Hakim, A., Masciottra,F.M., Zlatkes,R., Adissi,L., Neaton,J.,Dtal, M. and Losso, M.H. 2006. Prevention of Mother to Child Transmission. National Institute of Health. 66 (1): 24-30.*

12. Egesie, J. \& Egesie, G. (2011). Sero prevalence of Human Immuno deficiency Virus (HIV) among blood donors in Jos Nigeria. Cited in Barros E, 'HIV - infection: Impact, Awareness and social Implications of living with HIV/AIDS', In Tech Open, Retrieved on the October 262014.

13. Federal Ministry of health, (2010). National Guidelines on Prevention of Mother to Child Transmission of HIV in Nigeria. 4th ed. FMOH Abuja, FMOH.

14. Fact Sheet -HIV/AIDS, (2013). Available on http://www.unaids.org/en/media/unaids/contentassets/docum ents/epidemiology/2013/gr2013/20130923_FactSheet_Global en.pdf. Accessed on August 11, 2014.

15. Federal Ministry of Health, (2004).Technical Report, 2003. National HIV Sero-prevalence Sentinel Survey. Available on: www.nigeria-aids.org/pdf/2003sentinelSurvey.pdf.

16. Gottilieb, M.S.(2001). AIDS: Past and Future. New England Journal Med. 344: 1788-1791.

17. Hasan, H., Hassan, R., Khan,Z.R., Nuzhat, E. and Arefin, U. (2013). Influence of socio-demographic factors on awareness of HIV/AIDS among Bangladeshi garment workers. Springer Plus, 2:174.

18. Hecht, R., Alban, A., Taylor,K., Post, S.,Anderson, N., Schwarz, R.(2006). Putting it together: AIDS and the Millennium Development Goals. Plos Med, 3:11.

19. HIV/AIDS Statistics In Nigeria. (2014). The true story. Found from:http://www.nigeriahivinfo.com/hiv_aids_in_nigeria.php . Retrieved on August 18, 2014.

20. Imade,P., Ibadin, K., Eghafona,N., Enabulele,O., Ophori,E.(2010). HIV Sero-Prevalence among pregnant women attending antenatal clinic in a tertiary health institution in Benin City, Nigeria. Maced J Med Sci; 15:43-5.

21. Joint United Nation Programme on HIV/AIDS Epidemic (UNAIDS). Report on the global HIV/AIDS epidemicMay.2006)-

http://data.unaids.org/pub/globalreport/2006/2006_grexecutivesummary_en.pdf.

22. Khan,M.(2002). Knowledge on AIDS among female adolescent in Bangladesh:evidence from the Bangladesh demographic \& health service data. J Health Popul Nutr 20(2):130-137.

23. Mezie-okoye M.M.,Tobin-West C.I.,( Jun-Dec 2010). Uptake of prevention of mother-to-child transmission (PMTCT) of HIV services among pregnant women in Rivers State, Nigeria: a preliminary assessment. Journal of Community Medicine and Primary health care. 22(1):2.

24. Montagnier, L.(2002). Historical Essay: A history of HIV discovery. Science, 298(5599):1727-8.

25. Moses,O.A, Munir'deen,A.,and Peter,A.A.(2007). Awareness and Knowledge of mother-to-child transmission of HIV among pregnant women. J Natl Med Assoc. 99(7):758-763.

26. National Agency for the Control of AIDS (NACA 2009). National HIV/AIDS Policy Review report. Federal Government of Nigeria.

27. NACA Fact sheet August 2011. Update on HIV/AIDS Epidemic and response in Nigeria.

http://www.nigeriahivinfo.com/fact_sheets/hiv_fact_sheet_20 11.pdf. Accessed on August 11, 2013.

28. National Guideline for the Prevention of Mother to child transmission of HIV/AIDS in Nigeria (2010) - Federal Ministry of Health. http://www.emtct-iatt.org/wpcontent/uploads/2013/04/Nigeria_National-PMTCTGuidelines_2010.pdf.

29. Porbeni,I.A.,Emmanue,1 K.,Lloyd,J.,Richard, D.,William,S. \& Cecilia, H.,(2009). Efficacy of prevention of Mother to child transmission (PMTCT) in Rivers state,Nigeria .Published https://apha.confex.com/apha/138am/webprogram/paper2234 92.html; retrieved on Nov 72013.

30. Selwyn,P.A., Carter,R.J., Schoenbaum,E.E., Robertson, V.J., Klein,R.S. \& Rogers,M.F.(1998). Knowledge of HIV Antibody Status and Decision to Continue or Terminate Pregnancy Among Intravenous Drug Users. The Journal of the American Medical Association; 261(24):1-2.

31. Ukpe,I.S., Blitz, J., Hugo J. \& Theledi, M. (2009).The InfantFeeding Practices of Mothers Enrolled in the Prevention of Mother-To-Child Transmission of HIV Programme at a Primary Health Care Clinic in the Mpumalanga Province, South Africa. S.A Fam Prac 61 (4)337-339.

32. UNAIDS, (2004). Epidemiological Fact sheet Nigeria, up date. UNAIDS Report on the Global AIDS Epidemic. 2010. p. $10 . \quad$ Available from:nwww.unaids.org/en/media/unaids/contentassets/docum ents/unaidspublication/2010/20101123_globalreport_en.pdf. Accessed on July 42014.

33. UNAIDS Report on the Global AIDS Epidemic. 2013 UNAIDS / JC2502/1/E"-10. Available on http://www.unaids.org/en/media/unaids/contentassets/docum ents/epidemiology/2013/gr2013/UNAIDS_Global_Report_20 13_en.pdf. Accessed on July 19, 2014.

34. UNAIDS-WHO, Global Facts and Figures. 2009. Geneva

35. Uneka, C.J; Duhlinska, D.D \& Igbinedion, E.B.(2007). Prevalence and public health significance of HIV infection and anaemia among pregnant women attending antenatal clinics in Southern Nigeria. J Health Popul Nutr. 25:328-35.

36. UNICEF (2010).Nigeria PMTCT Factsheet. Available at http://www.unicef.org/aids/files/Nigeria_PMTCTFactsheet_2 010.pdf. Accessed on July 19, 2014.

37. World Health Organization,(2006 ). The global on women and AIDS. www.unaids.org.

38. WHO (2009). Global picture of PMTCT gap, Towards Universal Access. Progress Report. World Health Organization, Geneva.

39. WHO. (2010). New Progress and Guidance on HIV treatment. Available from: http://www.who.int/hiv/pub/arv/ARTfactsheet/en/index.html.

40. WHO/UNAIDS/UNICEF (2011) 'Global HIV/AIDS Response: Epidemic update and health sector progress report towards Universal Access.

http://www.unaids.org/sites/default/files/media_asset/201111 30_UA_Report_en_1.pdf 
Statistical Analysis of HIV/AIDS Awareness of Mothers: Ante-Natal Clinic of Braithwaite Memorial Specialist Hospital (BMH)

APPENDIX A: 2012 ESTIMATES

\begin{tabular}{|c|c|c|c|c|c|c|c|c|c|c|c|c|}
\hline & 2001 & 2002 & 2003 & 2004 & 2005 & 2006 & 2007 & 2008 & 2009 & 2010 & 2011 & 2012 \\
\hline $\begin{array}{l}\text { People } \\
\text { living with } \\
\text { HIV }\end{array}$ & $\begin{array}{l}30.0 \\
\text { million } \\
{[27.2 .33 .1} \\
\text { million] }\end{array}$ & $\begin{array}{l}31.0 \\
\text { million } \\
{[28.2 \cdot 34.1} \\
\text { million] }\end{array}$ & $\begin{array}{l}31.7 \\
\text { million } \\
{[28.9-34.8} \\
\text { million] }\end{array}$ & $\begin{array}{l}32.2 \\
\text { million } \\
{[29.4 \cdot 35.3} \\
\text { milion] }\end{array}$ & $\begin{array}{l}32.5 \\
\text { million } \\
{[29.7 \cdot 35.6} \\
\text { million] }\end{array}$ & $\begin{array}{l}32.8 \\
\text { million } \\
\text { [30.1.36.0 } \\
\text { milion] }\end{array}$ & $\begin{array}{l}33.2 \\
\text { million } \\
{[30.4 \cdot 36.3} \\
\text { million] }\end{array}$ & $\begin{array}{l}33.5 \\
\text { million } \\
{[30.7 .36 .7} \\
\text { million] }\end{array}$ & $\begin{array}{l}34.0 \\
\text { million } \\
\text { [31.1.37.1 } \\
\text { million] }\end{array}$ & $\begin{array}{l}34.4 \\
\text { million } \\
\text { [31.5-37.7 } \\
\text { million] }\end{array}$ & $\begin{array}{l}34.9 \\
\text { million } \\
\text { [31.9.38.3 } \\
\text { million] }\end{array}$ & $\begin{array}{l}35.3 \\
\text { millicn } \\
{[32.2 .38 .8} \\
\text { million] }\end{array}$ \\
\hline $\begin{array}{l}\text { Now HIV } \\
\text { Infections } \\
\text { (Total) }\end{array}$ & $\begin{array}{l}3.4 \text { million } \\
{[3.1 \cdot 3.7} \\
\text { million] }\end{array}$ & $\begin{array}{l}3.3 \text { million } \\
{[0.0-3.6} \\
\text { million] }\end{array}$ & $\begin{array}{l}3.1 \text { million } \\
{[2.9 \cdot 3.5} \\
\text { million! }\end{array}$ & $\begin{array}{l}3.0 \text { million } \\
{[2.7-3.3} \\
\text { million] }\end{array}$ & $\begin{array}{l}2.9 \text { million } \\
{[2.6 .3 .2} \\
\text { million] }\end{array}$ & $\begin{array}{l}2.8 \text { million } \\
{[2.5-3.2} \\
\text { milion] }\end{array}$ & $\begin{array}{l}2.7 \text { million } \\
{[2.4 \cdot 3.1} \\
\text { million] }\end{array}$ & $\begin{array}{l}2.6 \text { million } \\
{[2.3-3.0} \\
\text { million] }\end{array}$ & $\begin{array}{l}2.6 \text { million } \\
{[2.2 \cdot 3.0} \\
\text { million }]\end{array}$ & $\begin{array}{l}2.5 \text { mifion } \\
{[2.2 .2 .9} \\
\text { million] }\end{array}$ & $\begin{array}{l}2.5 \text { million } \\
{[2.1 \cdot 2.9} \\
\text { million] }\end{array}$ & $\begin{array}{l}2.3 \text { million } \\
{[1.9-2.7} \\
\text { million] }\end{array}$ \\
\hline $\begin{array}{l}\text { New HIV } \\
\text { infections } \\
\text { (odults) }\end{array}$ & $\begin{array}{l}2.8 \text { million } \\
{[2.6-3.1} \\
\text { million] }\end{array}$ & $\begin{array}{l}2.7 \text { million } \\
{[2.5-3.0} \\
\text { million] }\end{array}$ & $\begin{array}{l}2.6 \text { million } \\
{[2.3-2.9} \\
\text { million! }\end{array}$ & $\begin{array}{l}2.4 \text { million } \\
{[2.2 \cdot 2.7} \\
\text { million] }\end{array}$ & $\begin{array}{l}2.3 \text { million } \\
{[2.1 \cdot 2.6} \\
\text { million] }\end{array}$ & $\begin{array}{l}2.3 \text { million } \\
{[2.0-2.6} \\
\text { million] }\end{array}$ & $\begin{array}{l}2.2 \text { million } \\
{[2.0-2.5} \\
\text { million] }\end{array}$ & $\begin{array}{l}2.2 \text { million } \\
{[1.9-2.5} \\
\text { million] }\end{array}$ & $\begin{array}{l}2.2 \text { million } \\
{[1.9-2.5} \\
\text { million] }\end{array}$ & $\begin{array}{l}2.2 \text { mition } \\
{[1.9-2.5} \\
\text { million] }\end{array}$ & $\begin{array}{l}2.2 \text { million } \\
\text { [1.8-2.5 } \\
\text { million] }\end{array}$ & $\begin{array}{l}2.0 \text { million } \\
{[1.7-2.4} \\
\text { million] }\end{array}$ \\
\hline $\begin{array}{l}\text { Now } \\
\text { infections } \\
\text { (children) }\end{array}$ & $\begin{array}{l}550000 \\
{[500000-} \\
620000]\end{array}$ & $\begin{array}{l}560000 \\
{[510000-} \\
630000]\end{array}$ & $\begin{array}{l}580000 \\
{[520000-} \\
630000]\end{array}$ & $\begin{array}{l}550000 \\
(510000- \\
620000)\end{array}$ & $\begin{array}{l}540000 \\
{[490000-} \\
610000]\end{array}$ & $\begin{array}{l}520000 \\
{[470000-} \\
580000]\end{array}$ & $\begin{array}{l}480000 \\
{[440000-} \\
550000]\end{array}$ & $\begin{array}{l}450000 \\
{[410000-} \\
520000]\end{array}$ & $\begin{array}{l}400000 \\
{[360000-} \\
470000]\end{array}$ & $\begin{array}{l}360000 \\
{[330000-} \\
420000]\end{array}$ & $\begin{array}{l}310000 \\
1280000- \\
3700001\end{array}$ & $\begin{array}{l}260000 \\
(230000- \\
3200001\end{array}$ \\
\hline $\begin{array}{l}\text { ADS. } \\
\text { related } \\
\text { deaths }\end{array}$ & $\begin{array}{l}1.9 \text { million } \\
{[1.7 .22} \\
\text { million] }\end{array}$ & $\begin{array}{l}2.1 \text { million } \\
\text { (1.9.2.4 } \\
\text { million] }\end{array}$ & $\begin{array}{l}2.2 \text { million } \\
{[20.25} \\
\text { million! }\end{array}$ & $\begin{array}{l}2.3 \text { million } \\
(2.1 \cdot 2.6 \\
\text { million] }\end{array}$ & $\begin{array}{l}2.3 \text { million } \\
{[2.1 .26} \\
\text { million] }\end{array}$ & $\begin{array}{l}2.3 \text { million } \\
\mid 2.0 .2 .6 \\
\text { million } \mid\end{array}$ & $\begin{array}{l}2.2 \text { million } \\
{[1.9 .2 .5} \\
\text { million] }\end{array}$ & $\begin{array}{l}2.1 \text { million } \\
(1,8-2.4 \\
\text { million) }\end{array}$ & $\begin{array}{l}2.0 \text { million } \\
\lceil 1.7 .23 \\
\text { million! }\end{array}$ & $\begin{array}{l}1.9 \text { million } \\
{[1.7 .22} \\
\text { million! }\end{array}$ & $\begin{array}{l}1.8 \text { million } \\
{[1,6-2.1} \\
\text { million }\}\end{array}$ & $\begin{array}{l}1.6 \text { million } \\
{[1,4 \cdot 1,9} \\
\text { million] }\end{array}$ \\
\hline $\begin{array}{l}\text { People } \\
\text { accessing } \\
\text { treatment }\end{array}$ & & & & & 1.3 million & 2.0 million & 2.9 million & 4.1 million & 5.3 million & 6.6 mition & 8.1 million & 9.7 million \\
\hline Resources & & $\begin{array}{l}\text { U5s } 3.8 \\
\text { billion }\end{array}$ & $\begin{array}{l}\text { US5 } 4.6 \\
\text { billion }\end{array}$ & $\begin{array}{l}\text { Us5 } 5.7 \\
\text { billion }\end{array}$ & $\begin{array}{l}\text { USs } 7.4 \\
\text { billion }\end{array}$ & $\begin{array}{l}\text { US5 } 8.8 \\
\text { billion }\end{array}$ & $\begin{array}{l}\text { US5 } 10.5 \\
\text { billion }\end{array}$ & $\begin{array}{l}\text { US5 } 14.6 \\
\text { billion }\end{array}$ & $\begin{array}{l}\text { US5 } 15.5 \\
\text { billion }\end{array}$ & $\begin{array}{l}\text { US5 } 15.6 \\
\text { bellion }\end{array}$ & $\begin{array}{l}\text { US5 } 17.1 \\
\text { billion }\end{array}$ & $\begin{array}{l}\text { US5 } 18.9 \\
\text { billion }\end{array}$ \\
\hline
\end{tabular}

Source: http://www.unaids.org/en/resources/campaigns/globalreport2013/factsheet/ 
APPENDIX 2:2012 GLOBAL AND REGIONAL STATISTICS

\begin{tabular}{|c|c|c|c|c|c|}
\hline \multirow[t]{2}{*}{ Region } & \multicolumn{2}{|c|}{ People living with HIV 2012} & \multicolumn{2}{|c|}{$\begin{array}{l}\text { New HIV infections } \\
2012\end{array}$} & \multirow{2}{*}{$\begin{array}{l}\text { AIDS-related } \\
\text { deaths } 2012 \\
\text { (total) }\end{array}$} \\
\hline & total & children & total & children & \\
\hline $\begin{array}{l}\text { Sub-Saharan } \\
\text { Africa }\end{array}$ & $\begin{array}{l}25.0 \text { million } \\
\text { [23.5 million- } \\
26.6 \text { million] }\end{array}$ & $\begin{array}{l}2.9 \text { million } \\
{[2.7 \text { million - }} \\
3.3 \text { million] }\end{array}$ & $\begin{array}{l}1.6 \text { million } \\
\text { [1.4 million - } \\
1.8 \text { million] }\end{array}$ & $\begin{array}{l}230000 \\
{[200000-} \\
280000]\end{array}$ & $\begin{array}{l}1.2 \text { million } \\
\text { [1.1 million- } \\
1.3 \text { million] }\end{array}$ \\
\hline $\begin{array}{l}\text { South and } \\
\text { South-East } \\
\text { Asia }\end{array}$ & $\begin{array}{l}3.9 \text { million } \\
\text { [ } 2.9 \text { million- } \\
5.2 \text { million] }\end{array}$ & $\begin{array}{l}200000 \\
{[170000-} \\
270000]\end{array}$ & $\begin{array}{l}270000 \\
{[160000-} \\
440000]\end{array}$ & $\begin{array}{l}21000 \\
{[16000-} \\
32000]\end{array}$ & $\begin{array}{l}220000 \\
{[150000-} \\
310000]\end{array}$ \\
\hline East Asia & $\begin{array}{l}880000 \\
{[650000-} \\
1.2 \text { million] }\end{array}$ & $\begin{array}{l}8200 \\
{[5800-} \\
11000]\end{array}$ & $\begin{array}{l}81000 \\
{[34000-} \\
160000]\end{array}$ & $\begin{array}{l}1500 \\
{[<1000-} \\
3300]\end{array}$ & $\begin{array}{l}41000 \\
{[25000-64000]}\end{array}$ \\
\hline Latin America & $\begin{array}{l}1.5 \text { million } \\
\text { [1.2 million- } \\
1.9 \text { million] }\end{array}$ & $\begin{array}{l}40000 \\
{[32000-} \\
52000]\end{array}$ & $\begin{array}{l}86000 \\
{[57000-} \\
150000]\end{array}$ & $\begin{array}{l}2100 \\
{[<1000-} \\
4600]\end{array}$ & $\begin{array}{l}52000 \\
{[35000-75000]}\end{array}$ \\
\hline $\begin{array}{l}\text { Western and } \\
\text { Central } \\
\text { Europe }\end{array}$ & $\begin{array}{l}860000 \\
{[800000-} \\
930000\end{array}$ & $\begin{array}{l}1600 \\
{[<1300-} \\
2000]\end{array}$ & $\begin{array}{l}29000 \\
{[25000-} \\
35000\end{array}$ & $\begin{array}{l}<200 \\
{[<100-} \\
<200]\end{array}$ & $\begin{array}{l}7600 \\
{[6900-8300]}\end{array}$ \\
\hline North America & $\begin{array}{l}1.3 \text { million } \\
\text { [980 000- } \\
1.9 \text { million] }\end{array}$ & $\begin{array}{l}4500 \\
{[4000-} \\
5800]\end{array}$ & $\begin{array}{l}48000 \\
{[15000-} \\
100000]\end{array}$ & $\begin{array}{l}<200 \\
{[<200-} \\
<500]\end{array}$ & $\begin{array}{l}20000 \\
{[16000-27000]}\end{array}$ \\
\hline $\begin{array}{l}\text { Eastern } \\
\text { Europe and } \\
\text { Central Asia }\end{array}$ & $\begin{array}{l}1.3 \text { million } \\
1.0 \text { million- } \\
1.7 \text { million }\end{array}$ & $\begin{array}{l}19000 \\
{[16000-} \\
24000]\end{array}$ & $\begin{array}{l}130000 \\
{[89000-} \\
190000]\end{array}$ & $\begin{array}{l}<1000 \\
{[<500-} \\
1200]\end{array}$ & $\begin{array}{l}91000 \\
{\left[\begin{array}{ll}6 & 000-120000]\end{array}\right.}\end{array}$ \\
\hline Caribbean & $\begin{array}{l}250000 \\
{[220000-} \\
280000]\end{array}$ & $\begin{array}{l}16000 \\
{[14000-} \\
19000]\end{array}$ & $\begin{array}{l}12000 \\
{[9400-} \\
14000]\end{array}$ & $\begin{array}{l}<500 \\
{[<500-} \\
<1000]\end{array}$ & $\begin{array}{l}11000 \\
{[9400-14000]}\end{array}$ \\
\hline $\begin{array}{l}\text { Middle East } \\
\text { and North } \\
\text { Africa }\end{array}$ & $\begin{array}{l}260000 \\
{[200000-} \\
380000]\end{array}$ & $\begin{array}{l}20000 \\
{[14000-} \\
31000]\end{array}$ & $\begin{array}{l}32000 \\
{[22000-} \\
47000]\end{array}$ & $\begin{array}{l}3000 \\
{[2000-} \\
4600]\end{array}$ & $\begin{array}{l}17000 \\
{[12000-26000]}\end{array}$ \\
\hline Oceania & $\begin{array}{l}51000 \\
{\left[\begin{array}{ll}43 & 000- \\
59 & 000]\end{array}\right.}\end{array}$ & $\begin{array}{l}3100 \\
{[2400-} \\
4100]\end{array}$ & $\begin{array}{l}2100 \\
{[1500-} \\
2700]\end{array}$ & $\begin{array}{l}<500 \\
{[<200-} \\
<500]\end{array}$ & $\begin{array}{l}1200 \\
{[<1000-1800]}\end{array}$ \\
\hline Global & $\begin{array}{l}35.3 \text { million } \\
\text { [32.2 million- } \\
38.8 \text { million] }\end{array}$ & $\begin{array}{l}3.3 \text { million } \\
{[3.0 \text { million- }} \\
3.7 \text { million] }\end{array}$ & $\begin{array}{l}2.3 \text { million } \\
\text { [1.9 million- } \\
2.7 \text { million] }\end{array}$ & $\begin{array}{l}260000 \\
{[230000-} \\
320000]\end{array}$ & $\begin{array}{l}1.6 \text { million [1.4 } \\
\text { million- } \\
1.9 \text { million] }\end{array}$ \\
\hline
\end{tabular}

Source: http://www.unaids.org/en/resources/campaigns/globalreport2013/factsheet/ 